\title{
Tarihin "Öteki” Yüzü: Türkiye ve Yunanistan Örneğinde Tarihi Yeniden
}

\section{Algılamak}

\author{
The "Other" Face of History: Re-comprehending History in the Example \\ of Turkey and Greece
}

\author{
Esra ÖZSÜER*
}

\begin{abstract}
Öz: Çocukluk yıllarında okuduğumuz öykülerin içindeki imgelerin kişiliğimizin oluşmasında, davranışlarımızın biçimlenmesinde, hayal ve hedeflerimizin belirlenmesinde, algılama estetiğimizin oluşumunda büyük bir etkisi olduğu bilinir. Bu nedenle bu dönemde okunan kitaplar ve özellikle de okul kitapları kişinin ruhsal, bireysel ve toplumsal biçimlenmesinde ve kimlik oluşumunda etkin bir rol üstlenir. Kitaplardaki "öteki" algısının bireyin tüm hayatını etkileyen ve önyargıları oluşturan ilk basamak olduğu görüşü doğru bir tespit olacaktır. Özellikle tarih kitaplarında yer alan ifadeler "öteki"nin imajını belirlemede ilk ve temel etkendir. Türkiye ve Yunanistan çerçevesinde ise "öteki" kendini pek çok sosyal, kültürel ve siyasal alanda gösteren bir kavramdır. Özellikle her iki ülkenin tarih anlatımında "öteki"ne ait imajlar ulus kimliğinin inşasında da önemli bir rol üstlenmektedir. Bu çalışmada Türkiye ve Yunanistan'daki çocuklara yönelik popüler tarih kitaplarındaki ortak tarih algısı karşılıklı incelenerek "öteki" ve "ben" algısının nasıl oluştuğu saptanmaya çalışılmıştır. Araştırma yöntemi nitel içerik ve doküman analizine dayanmaktadır. Her iki ülkede çocuklar için hazırlanan popüler tarih kitaplarındaki ortak tarih algısı "öteki" üzerinden irdelenmiş ve aynı tarihi olayın neredeyse birbirine zıt iki farklı anlatımı karşılaştırmalı metot kullanılarak ifade edilmeye çalışılmıştır.
\end{abstract}

Anahtar Kelimeler: Öteki, İmaj, Türkiye/Yunanistan Tarihi, Algı, Ulusal Kimlik

Abstract: The images in the stories we read in our childhood have a deep impact on the shaping of our characters, behaviours, dreams and aims as well as the formation of our aesthetics of perception. The books read in this period of life play important role in mental, individual and social formation of the person and his identity. The perception of "Other" in books is the first step in the construction of prejudices affecting an entire life. The expressions in history books, in particular, are the first and fundamental factors in determining the image of the Other. Within the framework of Turkey and Greece, the Other manifest itself in many social, cultural and political arenas. The images of Other in each state's historiography play important roles in construction of national identity. This paper comparatively studies the perception of history in popular history books for children in Turkey and Greece and examines the process of how Self and Other are constructed. The research method is based on qualitative content

* Dr. Esra Özsüer, İstanbul Üniversitesi, Avrasya Enstitüsü, ozsueresra@gmail.com 
and document analysis. The perception of common history in popular history books for young readers are examined with the perspective of Other. That the same events have two opposing narratives in these countries are displayed through comparative methods. Identity

Keywords: Other, Image, Turkish History, Greek History, Perception, National

\section{Giriş}

Düşman kimdir? Her ulus düşman saydığı "öteki”yi nasıl seçer? Okul, aile, dini otorite, kitle iletişim araçları, siyasiler, politik etmenler, uluslararası çevre, aydınlar halkın kolektif belleğinin ve ortak düşüncesinin şekillenmesine nasıl katkıda bulunurlar? Örneğin pek çok kez farkına varmadan kullandığımız bazı deyimler ya da ifadeler zamanla nasıl bilinçaltımızda kalıp yargılara (stereotipler) dönüşür? Tüm bu sorular kendi “öteki”sini yaratan ulusların çoğu zaman farkında olmadan oluşturduğu imajlarla yakından ilintilidir. Kendi ulusal varlığını "öteki”nin varlığına bağlayarak iç birliktelik oluşturmak ve oluşturulan bu birliği "öteki" karşısında korumak ulusdevletlerin bekasında önemli ölçütlerdir. Bu konuda verilebilecek en iyi örneklerin başında ise Türkiye ve Yunanistan gelmektedir. Örneğin, her iki ülkenin dilinde "öteki" olarak gördükleri karşı tarafla ilgili benzer olumsuz ifadelerin yer alması zamanla kolektif bellekte "öteki”nin kötü imajının daha kalıcı olmasına yardımcı olmuştur. "Yunan'dan dost, ayıdan post olmaz" sözü karşısında "Türk'ten dost olmaz çünkü arkadan vurur" (O Tourkos den pianetal filos giati eınaı babesis/O ToúpкоS $\delta \varepsilon v$

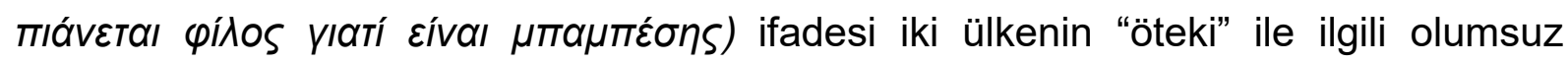
yargılarını açıklar niteliktedir. Benzer bir diğer örnek her iki dilde vatanına ihanet edenler için kullanılan "Yunan tohumu" ya da "Türk tohumu" (tourkosporos/точрко́бпороS) benzetmelerinde de görülmektedir. Yine Yunancada "Egina Tourkos/Eyıva Toúpкos" (Türk oldum) deyimi çok sinirlenmek, çığııından çıkmak anlamında kullanılır. Bir başka deyişle Türk ve Yunan kelimeleri çoğu zaman ihanet, düşmanlık, hainlik gibi olumsuz yargılarla bir tutulmaktadır. Tüm bu olumsuz ifadeler ve tanımlamalar da genellikle bilinçaltına kötü imajlar ve ön yargılar olarak inerek "öteki"nin her zaman önlem alınması gereken bir tehdit unsuru biçiminde görülmesini sağlamıştır.

Türkiye ve Yunanistan arasındaki ikili ilişkiler tarihi süreç içerisinde her zaman belli bir istikrarda devam etmemiştir. Kimi zaman bu ilişkiler düşmanca kimi zaman da dostane bir çerçevede seyir almıştır. Bir tarafın tarihinde önemli sayılan olaylar kimi 
zaman diğer tarafın varığı ile ilişkilendirilmiş ve yine bir tarafın en görkemli tarihi anı bazen ötekinin yenilgisi ve felaketiyle anlam kazanmıştır. Kısacası Türk-Yunan ilişkilerinde temel rol oynayan ortak tarihi geçmiş çoğunlukla "öteki" ile arasındaki zıtlıklar üzerine kuruludur. Örneğin Yunan Devletinin kuruluşu olan 1821 Mora İsyanı, ${ }^{1}$ Yunan tarih yazımında Osmanlı İmparatorluğuna karşı verilen sekiz senelik askeri bir mücadeledir. Oysa aynı tarih, Türk tarih yazımında Osmanlı İmparatorluğunun içerden yıkımını (Millas, 2005: 25) başlatan bir isyan hareketi olarak ifade edilir. Benzer bir durum her iki ülkenin 1922 tarihini algılama ve sunma biçiminde de görülmektedir. Türkiye Cumhuriyetinin kuruluş aşamalarından biri sayılan 1922, Türk tarih yazımında Yunanlılara karşı kazanılan askeri bir zaferken; Yunan tarih yazımında ise Megali İdea'nın (Büyük Mefkure) çöküşünü temsil eder. Öyle ki, dünya tarihi için ender sayılabilecek bu mütekabiliyette her iki taraf kendi tarihinin zirve yerlerinde "öteki"ne düşman rolünü vermiş ve "öteki”nin ulus kimliğinin oluşmasında önemli bir rol üstlenmiştir. Elbette ki "öteki”nin olmadığı bir toplumun varlığından söz etmek zordur. Çünkü "öteki” bir toplumun kimliğinin oluşmasında etkin bir görev üstlenir. Tarihin belli dönemlerinde pek çok ulus “öteki”ne karşı "ben/biz" yönelimiyle varlığını sürdürmüş ve ulus kimliğini güçlendirmiştir. Örneğin Filistin için İsrail, Fransa için Almanya, Hırvatistan için Sırbistan, Japonya için Çin, Yunanistan için Türkiye tarihin belli dönemlerinde karşılıklı olarak birbirlerini ötekileştirmiş ve tarih söylemlerinde "öteki"ne ait unsurları zıtlıklar üzerinden açıklamışlardır. Mesela Yunanlılar için Yunan devrimi, Türkler için Yunan isyanıdır. Türkler için İzmir'in işgali, Yunanlılar için İzmir'in kurtuluşudur. Yine Yunanlılar için Türklerin Kıbrıs'a zorla girmesi, Türkler için Kıbrıs Barış Harekâtıdır. Türk-Yunan ortak tarihi genellikle birbirini tanımlayan bu tür zıtlıklar üzerine kurulu bir düzenek içinde yer alır. Her iki tarafın da kendi cephesinden tanımladığı bu ortak tarih algısı aslında aynı olayların farklı perspektiflerden bakılıp yorumlanmasıdır. Nitekim bireyler ve toplumlar kendi kimliklerini sadece kültür ve tarihleriyle değil aynı zamanda "öteki”nin varlığıyla da oluşturdukları için karşıtıı kaçınılmazdır (Güvenç, 1998: 24).

Türkiye ve Yunanistan coğrafi yakınlığın yanı sıra tarihi, sosyal, politik ve folklorik açıdan da birbirleriyle güçlü bağları olan iki toplumdur. Her iki toplumun dilinde birinden diğerine geçmiş ortak kelimeler, ifadeler bulunmakla birlikte günlük hayatın

\footnotetext{
1 Türk tarih yazımında isyan olarak adlandırılan bu süreç Yunan tarih yazımında 1821 Yunan
} Ayaklanması (Ellinikos Ksesikomos) ya da Yunan Devrimi (Elliniki Epanastasi) olarak tanımlanmaktadır. 
içinde de benzer gelenek ve göreneklere rastlamak mümkündür. Tüm bu benzerliklere rağmen iki toplum ulus birliğini oluşturma adına geçmişte "öteki"ni korku duyulması ve önlem alınması gereken bir dış unsur olarak nitelendirmiştir. Yunanistan, Türkleri ezeli bir düşman olarak tanımlarken; Türkler de Yunanları yıllardan beri devam eden ebedi düşmanlarından biri varsayar. Ancak her iki ülke ilişkilerinde dönem dönem yaşanan siyasi dalgalanmalar, toplumsal ilişkileri olumlu/olumsuz yönde etkileyerek imajların da değişkenliğini beraberinde getirmiştir. Buna verilebilecek en güzel örnek Türkiye ve Yunanistan'da peşi sıra gerçekleşen 1999 depremidir. İki ülkenin ortak acı olarak kabul ettiği bu olayın akabinde gerçekleşen karşılıklı destek ve yardımlaşma iki toplum arasında süregelen olumsuz stereotiplerin (kalıp yargılar) değişmesine de olanak sağlamıştır. Türkiye ve Yunanistan dostluk ekseninde milat olarak kabul edilen '99 depremi ile "öteki" kavramı nispeten geçmiş yıllara oranla daha az olumsuz imajları içinde barındırmaya başlamış ve iki ülke arasında dostluk köprülerinin kurulmasına olanak sağlamıştır. Fakat toplumlar arasında sosyal gerilimlerin tekrardan ortaya çıkması sosyal algıda daha çok stereotip (kalıp yargı) ve ön yargı geliştirdiğinden (Bodenhausen, Sheppard \& Kramer, 1994: 45-62) iki ülke arasında var olan bu olumlu atmosferin herhangi bir siyasi karmaşadan etkilenme ve bozulma tehdidi hiçbir zaman gözden kaçırılmaması gereken bir detaydır. Üzerinde durulması gereken bir diğer husus; değişen siyasi yönetimlerin iki ülkenin tarih yazımına doğrudan etki etmesidir ya da kimi zaman müdahil olmasıdır. İmajları besleyen ön yargıların iktidarlar tarafından inşa edildiği (Tekeli, 1998: 5) düşünüldüğünde iktidarın siyasi eğilimine paralel izdüşümlere sahip eğitim politikaları da özellikle iki ülke tarih kitaplarındaki "öteki” tasvirini doğrudan etkilemiştir. ${ }^{2}$ Bu tür siyasi ve toplumsal değişimlerin yarattığı sonuçlar Türkiye ve Yunanistan ekseninde var olan "öteki" ile ilgili tanımlamaların durağan bir çizgi dışında incelenmesi gerekliliğini de beraberinde getirir.

Genel çerçevede Yunanlar "öteki” saydığı Türklere kendilerini Avrupa'dan soyutlayan ve geri bırakan olumsuz bir tarihi sorumluluk yüklerken; Türkler de Yunanları 1821 Yunan İsyanı ile Osmanlı'nın Balkanlar'da ilk toprak kaybını başlatan ve sonrasında Megali İdea ile topraklarını işgal eden düşman olarak nitelendirmiştir. Her iki ulusun yüklendiği bu tarihi miras bir ulusun diğerinin imajının belirlenmesinde oldukça etkin bir rol oynamıştır. Aslında iki ulusun birbirlerini bu tarihi ölçütler içinde

\footnotetext{
${ }^{2}$ Bu konuda detaylı bir çalışma için bkz: Bilginer, 2012.
} 
ötekileştirmesi Türkiye ve Yunanistan'ın ulusal yalnızlığını onaylayan ve pekiştiren sosyolojik bir sonuç da yaratmıştır. "Türkün Türk'ten başka dostu yoktur" ifadesine paralel "Yunanlar kardeşsiz bir ulustur" (Oı Ellines eımetha Ethnos Anadelfon/Oı

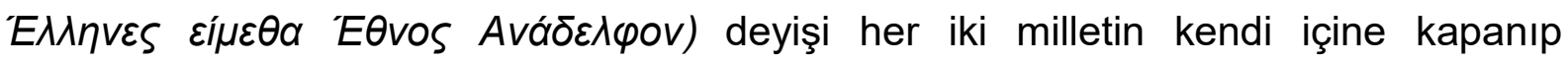
yalnızlaşmasına ve "öteki"ni net çizgilerle dışlamasına sebebiyet veren bir mekanizma oluşturmuştur. Bu ötekileştirme mekanizması daha sonraki süreçte iki ulusun da kendisi dışında hiç kimseye güvenmemesini ve "öteki”ni düşman ya da tehdit unsuru olarak görmesini kolaylaştıran imajları yaratmıştır. Olumsuz stereotiplerin (kalıp yargılar) ve önyargıların beslediği "öteki” algısı bir bakıma Türkiye ve Yunanistan'ın ulus kimliğinin kurulmasında etkin bir rol üstlenmiştir (Özsüer, 2012: 271).

Türkiye ve Yunanistan'ın ulusal hafızasında oluşturduğu "öteki” algısı ve imajlar daha çok her iki ulusun birbirlerini düşman olarak gördüğü tarihi olaylar etrafında şekillenmektedir. Bunun sebebi önyargıların, kötüye kullanma bakımından, kendisini daha çok biyoloji, antropoloji ve tarihte göstermesi olarak açıklanabilir (Tekeli, 1998: 3). Çünkü her tarihi olay kendi içinde düşman saydığı bir “öteki”yi ve karşıtlığın sembolü olan "öteki”yle mücadelesini barındırır. Nitekim sosyal psikolojinin de desteklediği görüşe paralel olarak politik ve tarihi olaylar imajların oluşumunda oldukça etkin bir görev üstlenmektedir. Ortak tarihi miras Türkiye ve Yunanistan'ı birbirine bağlayan tarihi normları yaratmanın dışında iki ulusun bu tarihi çerçevede birbirleriyle çelişmesine/çatışmasına sebebiyet veren itici bir güç de oluşturur. Bunun başlıca nedeni de iki ulusun sahip olduğu ortak tarihi kendi cephesinden yorumlaması ve bu bakış açısıyla algıya sunmasıdır. Nesnel tarihin olmadığını ifade eden Carr, aynı zamanda tarihin önyargılardan bağımsız düşünülemeyeceğini de vurgular (Carr, 2013: 12-14). Nitekim her iki ülke de kendi tarihlerine objektif kalamamış ve "ben" gözünden “öteki”ni bu tarihe sığdırmıştır. Bu bağlamda düşünüldüğünde her iki taraf çoğu zaman aynı tarihi olayı sübjektif bir gözle birbirine tezat yorum ve anlatılarla ifade etmişlerdir.

Bu makalede amaç, Türkiye ve Yunanistan'ın ortak tarihi geçmişlerinden yola çıkarak birbirini nası tanımladığını ve aynı tarihi olayları ne şekilde yorumladığını karşılaştırmalı metot ${ }^{3}$ kullanarak ele almaktır. Makalede ele alınan kitaplar ders kitaplarının dışında kalan tarih içerikli popüler çocuk kitaplarıdır. Bu kitapların seçilme nedeni tarihin hikâye edilebilecek bir malzeme olarak, resmi ideoloji ile okutulan okul

\footnotetext{
${ }^{3}$ Bu konuda kapsamlı bir çalışma için bkz, Agorastou, 1992.
} 
kitaplarından farklı, olayları nası yorumladığını incelemektir. Nitekim zorunlu olan okul kitaplarındaki tarihi bilginin bireyin kendi seçimiyle ve isteğiyle aldığı ders dışı kitaplardan öğrenmesi daha kalıcı imajların oluşumuna yardımcı olur. ${ }^{4}$ Böyle bir tarih anlatısı imajların daha belirgin ve daha istenileni verme gayesiyle örtüştüğünden önemli bir inceleme konusu olarak nitelendirilebilir.

\section{Yöntem}

Araştırmanın içinde yer alan kitapların seçimi Glaser ve Strauss tarafından geliştirilen gömülü teori (grounded theory) sosyolojik metoduna dayanmaktadır. Tarih içerikli çocuk kitaplarının seçilmesinde konunun Türkiye ve Yunanistan ortak tarihini içermesi, kitabın konu başlığı, hikâye içinde yer alan kahramanların kimliği ve kitapların çocuklara yönelik yaş aralığında olması dikkate alınmıştır. Araştırmada seçilen kitapların içindeki verilere göre yorumlanmasında tümevarım yöntemi kullanılmış ve elde edilen bu bilgiler sonucunda araştırma belli bir teoriye bağımlı kalmadan kendi teorisini oluşturmuştur. Bir başka ifadeyle bu araştırmada kullanılan gömülü teori, İspanyol şair Antonio Machado'nun "yol yoktur, yolu yürüyerek oluşturursun” sözüyle açıklanabilir. İncelenen kitaplarda yer alan konular her iki ülke tarihinde önemli addedilen 1453, 1821 ve 1922 yıllarını içermektedir. Bu dönemlerin iki ülkenin tarih anlatımında nasıl şekillendiği, "öteki" ve "ben" ilişkisini nasıl konumlandırdığı karşıllaştırmalı bir şekilde incelenmiştir. Amaç Türk ve Yunan algısında "öteki"ni göstermekten ziyade "biz"im kim olduğumuzun sonucuna da varabilmektir. Özellikle iki ülke tarihinin bu minvalde bir propaganda aracı olarak kullanılması bilimsel yönüne de ters düşen bir sonucu doğurur. Her iki toplum için "pop culture" sayılabilecek bu kitaplardaki tarih anlatısı okul kitaplarında geçen "öteki”nin algı ve imajını dimağa daha kolay yapıştıran bir tutkal görevi de görmektedir. Neticede seçilen bu kitaplarda yer alan "öteki" ile ilgili ifadelerin özünde okul kitaplarındaki anlatımları tamamladığı ve desteklediği bizzat gözlemlenmiştir.

\footnotetext{
${ }^{4}$ Bu konu ile ilgili kapsamlı bir çalışma için bkz: Özsüer, 2015.
} 


\section{Bulgular ve Tartışma}

Çalışmanın bu bölümünde Türkiye ve Yunanistan tarihinde önemli sayılan üç tarihi dönem, Türkçe ve Yunanca popüler çocuk kitaplarında karşılıkı ele alınarak irdelenmiş ve kitaplarda yer alan "öteki” ile "ben/biz" kurgusunun nasıl oluşturulduğu detaylı bir biçimde incelenmiştir.

\section{3 İstanbul'un Fethi mi? Bizans'ın sonu mu?}

1453 İstanbul'un Fethi, sadece Türkiye ve Yunanistan ulus tarihinde tarihi bir kırıma noktası olmayıp aynı zamanda dünya tarihi açısından da önemli bir dönemeç kabul edilir. Dünya Tarihinde 1453 yılının sembolik değeri bir çağın kapanıp yeni bir çağın başlamasından farklı düşünülmezken, Türk ve Yunan Tarihi, kendi tarih anlatımlarında aynı olayı iki farklı cepheden inceler. Yunan (Bizans) Tarihi için 1453, Bizans İmparatorluğunun nihai sonunu getiren ve Yunanistan için yıllarca sürecek olan karanlık bir dönemin habercisidir. Oysa aynı tarih Türk (Osmanlı) tarihinde topraklarını genişleten Osmanlının bir dünya gücüne dönüşmesini sağlayan yeni bir tarihi başlangıçtır. Türk tarih kitaplarında fetih olarak ifade edilen İstanbul'un Türkler tarafından ele geçirilmesi aynı zamanda $\mathrm{Hz}$. Muhammed'in "Istanbul'u fetheden komutan ne güzel komutandır, Istanbul'u alan asker ne güzel askerdir" hadisinin yerine getirilmesi bakımından dini manada özel bir görev de yüklenir. Yani Türk tarih yazımında İstanbul'un Fethi'nin meşru kılınmasının temeli ahlaki boyutunun yanı sıra aynı zamanda dinidir (Copeaux, 1998: 80). Fetih, barış̧̧ıl bir ruh ile yola çıkan Türklerin, Bizans'ın baskı ve şiddet gösterdiği Anadolu halklarını İslam'ın kapsayıcılığı ve adaletiyle kurtaran, "geçtiği yerlere billur bir ırmak gibi bolluk, temizlik aşılayan ..." (Boyunağa, 2011: 80) münferit çabasıdır. "Türkler fetih ülküsüyle ülke topraklarını genişleterek ulaştıkları her yerde barışı ve adaleti tesis etmeye çalışırlar" (Dikmen, 2012: 44). Oysa "öteki" taraf için bu tarihi kesit İstanbul'da bulunan Ortodoks Patrikhanesinin uzun vadede gücünü yitirmesi ve Hıristiyan dünyasının büyük yenilgisiyle başlayan tutsaklık ve karanlık yıllarının başladığı tarihtir. Her iki ülkenin 1453 algısı madalyonun iki yüzü gibidir. Bu zıtlık dönem algısındaki farklıığı da keskin çizgilerle belirler. "Ben"in başladığı yerde "öteki" son bulur. Zira karşıtığın tarihte ne kadar etkin olduğu da bilinen bir gerçektir (Barthes, 2012: 37-46). 
1453 İstanbul'un Fethi ile Türkler ve Bizanslılar tarih sahnesinde ilk kez karşılaşmamışlardır. Her ne kadar erken Ortaçağ'da Oğuzlar ve Bizansılıarın yolları tarihte pek çok defa kesişse de, iki ülkenin tarih anlatımlarında ilk karşılaşma Selçuklular ve Bizans arasındaki ilk büyük savaş olan 26 Ağustos 1071 Malazgirt Muharebesidir. Özellikle Türk tarih kitaplarında Selçukluların Bizans'ın yenilgisiyle sonuçlanan Anadolu topraklarındaki bu askeri başarısı o döneme kadar Bizans İmparatorluğunun denetiminde olan bu topraklara İslam sayesinde barışı ve huzuru getiren bir zafer olarak da sunulmaktadır. Yunan bakış açısıyla aynı tarihi olay, Osmanlı İmparatorluğu'nun kuruluşuna götürecek süreci başlatan ilk ciddi adımdır. Nitekim tam bir asır sonra 26 Ağustos 1922'de Yunanlıların Başkomutanlık Meydan Muharebesinde Türklere karşı ağır yenilgisi de Yunan tarihinde benzer bir biçimde Türkiye Cumhuriyetinin kurulmasına sebep olan bir tarihi tekerrür gibi algılanır. Türk tarihi açısından önemli addedilen Malazgirt ve Başkomutanlık Meydan Muharebelerinde (Büyük Taarruz) mücadele ettiği tarafın Yunan ile bağlantılı olması ve Yunan'a karşı verilen bu askeri zaferlerin sonucunda iki önemli tarihi başlangıcın yaşanması, Türkler açısından Yunanların "milli öteki" olarak kabulünü sağlar. Yunanlarla karşı karşıya geldikleri her iki askeri mücadelenin de aynı güne denk gelmesi (26 Ağustos) ve her iki ulusal kahramanın (Alparslan-Atatürk) ahlaki faziletleri arasında kurulan benzerlik, Malazgirt Savaşı ve Büyük Taarruz arasında da birbirini bütünleyen tarihi zincirin kurulmasına olanak sağlamıştır. Kısaca, Türk tarih tezinde Malazgirt, 1922'de Atatürk'ün Yunan ordularına karşı zaferiyle kapanan tarihi sürecin de başlangıcı sayılır (Copeaux, 1998: 78). Böylesi uzun bir dönemin içinde yer alan Yunanlar, tarihin diğer dönemlerinde de, 1821 Mora İsyanı, Balkan Savaşları, Kurtuluş Savaşı, Kıbrıs Olayları vb. Türklere sürekli sorun çıkaran bir millet görüntüsündedir. Yani Türkler için "milli öteki" sayılan Yunanlar her dönem mücadele edilmek zorunda kalınan yakın/komşu düşman olarak görülmüştür.

Malazgirt Muharebesi ile Anadolu'nun kapılarının Türklere açılması tarihi akışta Türk ve Yunan temaslarını devam ettirecek önemli bir başlangıçtır. Bu sürecin her iki tarih bakımından en önemli olgusu, 1453 İstanbul'un alınmasıdır. Sadece Türk ve Yunan tarihi için değil aynı zamanda dünya tarihi için de önemli bir başlangıç sayılan 1453, Türk tarihinde şanlı bir zafer olması nedeniyle tarih anlatılarında sıklıkla kullanılan bir dönemdir. Oysa Yunan tarihinde "sonun başlangıcı" olarak karşılık bulan Bizans'ın düşüşü, bu dönemi kendisine konu alan kitaplarda detaya inmeden ve genel 
çerçevenin dışına çıkılmadan ifade edilir. Her iki ülke kitaplarında zafer, daha ayrıntılı ve derin bir perspektifle sunulurken yenilgi, suskunlukların ve yüzeysel anlatımın ötesine geçmez. Bunun nedeni toplumun "öteki”lere kıyasla farklı ve özel olan yanlarını sergileyip tanınma çabasıdır (Bilgin, 1994: 144-146). Hiçbir toplum kendini diğer topluma olumsuz sunmak istemez. Bu nedenle de kendi toplumunu diğer topluma kıyasla kahraman ve daha üstün gösterme çabası içine girer. Bunu da "ben" ve "öteki”ni kıyaslayarak gerçekleştirir. Bu kıyaslamada "ben” "öteki”lerden eksik değilim yerine "ben" "öteki”lerden daha fazlayım yöntemi kullanılır. Böylece 1453, Türk kitaplarında coşkulu kahramanlık destanlarının tarihi anlatısında etkin bir malzeme iken, Yunan kitaplarında tek düze bir anlatımla geçiştirilmeye çalışılan tarihi bir yenilgidir. Bu dönemi konu edinen pek çok Yunanca kitapta Türkler, Agarinos, Haldupis, Mongolis vs gibi küçültücü ifadelerle anılan Asyalı barbarlar olarak gösterilir. Döneme ilişkin Türkçe kitaplarda ise Yunan kavramı henüz mevcut değildir. Türklerin karşısındaki "düşman öteki" Bizans Rumlarıdır. Özellikle Bizans, Rum ve Yunan kavramlarının net çizgilerle ayrılamadığı çoğu Türkçe kitapta dil (Yunanca) ve din (Ortodoks) birliğinden dolayı bu üç kimlik etnik olarak aynı grup üyelerinin farklı zamanlardaki biçimi olarak sunulur. Nitekim bu bağ Yunan tarihinin de ulus-devlet yapılanması içinde desteklediği bir durumdur. Atalarını Antik Yunan'a bağlayan Modern Yunanlar aynı zamanda Bizans'ı da kendi uluslarının bir devamı sayarlar. Böylelikle bir ulusun devamlıı̆ını tehlikeye düşürecek büyük tarihi boşluğun da önüne geçilmiş olunur. (Veremis, 2012: 28) Neticede; böylesi bir tarihi boşluğun varlığı ulusdevletlerin tarihi süreklilik ispatı için de bir anti tez niteliğindedir (Özkırımlı ve Sofos, 2013: 6-7). Türkçe kitaplarda Türk kavramının karşıı̆ı̆ı ise dönem itibariyle Selçuklulardır. Günden güne güçlenen ve o dönem Bizans İmparatorluğu sınırları içinde yer alan Anadolu topraklarını ele geçiren Selçuklular karşısında Bizans İmparatorluğu eski gücünü yitirmiş, köhnemiş ve yıkılmaya yüz tutmuş güçsüz bir imparatorluk olarak çaresizlik içinde kaçınılmaz sonunu bekler. Kitaplarda kendi halkına bile eziyet eden, baskı kuran (Subaşı, 2011: 21) Ortodoks Bizans'ın İstanbul'a layık olmadığı, İstanbul'un Türk-İslam kimliğine büründükten sonra huzura kavuşacağı vurgulanır. Yani diğer bir ifadeyle "Istanbul Müslüman Türklere yaraşmaktadır" (Boyunağa, 2011: 118). Bizans'ın adaletsizliği ve baskısı karşısında kendi halkı adalet, eşitlik ve huzurun garantisi gördüğü Osmanlı hegemonyasını tercih eder (Okay, 2010: 163). "Kendi halkında huzur bırakmayan Bizans'ın bu kokuşmuş düzeni sona ermeli ve İstanbul Türklerin adaletli ellerine düşmelidir” (Dursun, 2010: 29). Bu durum çoğu 
zaman kitaplarda Bizans içinden bir Rum'un yani "öteki”nin, Türkler ile ilgili olumlu konuşturulmasıyla da onay alır. "Kahrol Bizans! Imparator elindeki Türk esirlerini vicdansız kasaplar gibi doğrayıp surlardan aşağı atarken, intikam alması gereken padişah kendine karşı silah çekenleri affediyor. Herhalde zavallı imparatorumuzun ve bizim, Ayasofya'dan çıkıp gelerek bizi Türklerden kurtarmasını beklediğimiz melek, bu padişah olmalı" (Dursun, 2010: 73). Böylelikle "öteki” hakkında var olan olumsuz kalıp yargıların tekrarlanması "öteki"nin imajını yeniden olumlu yönde kuran bir mekanizma görevi üstlenir. Yani "ben” "öteki”ni kendi silahıyla vurur (Abatzapoulou, 1998: 322). Elbette ki İstanbul'un fethine yönelik bu tür anlatımlar Yunan kitaplarında şehrin işgali ve düşüşü olarak algılandığından kullanılan ifadelerde daha çok bir devrin sonu olarak bahsedilir. Türkçe kitaplarındaki anlatımların tam aksine Yunanca kitaplar Bizans döneminde Anadolu'da herhangi bir baskı, şiddet ve dini tehdittin varlığından bahsetmez. Şehrin düşüşü bir zamanların güçlü imparatorluğu Bizans'ın artık yaşlanıp yorgun düşmesinden ötürü başka halklarca topraklarının işgal edilmesi şeklinde açıklanır (Servi, 2011: 8). Kısacası, İstanbul'un Bizans'ın elinden çıkması direnç gösterecek gücü olmayan, çökmekte olan bir imparatorluğun doğal bir sonucudur (Servi, 2011: 8). Oysa Türkçe kitaplarda İstanbul'un fethi Hıristiyan Bizans'ın Müslüman Türklere yaptığı zulmü de sona erdiren bir kurtuluş destanı olarak sunulur.

Bizans uzun zaman Müslümanlara türlü türlü işkenceler, akla hayale gelmedik şekilde acılar çektirdi. Çocukların genç kızların ve kadınların çığlıkları göklere yükseldi. İşte o sırada Müslüman Türkler Bizans'ın karşısına dikildiler. Bizans'ın vahşet destanı biterken, Anadolu toprakları o zamana kadar görmediği muhteşem bir destan gördü ve yaşadı... (Boyunağa, 2011/b: 6-7).

Yunanca kitaplarda işgal, Türkçe kitaplarda fetih olarak gösterilen İstanbul'un alınması her iki tarafın aynı tarihi olaya kendi bakış açılarından bakması ve yorumlaması sonucu taban tabana zıt ifadeleri doğurmuştur. Türk tarafı için askeri bir zaferin Yunan tarafı için karşılığı Bizans'ın sonudur. Yunan kitaplarında bu yenilginin temel nedeni Osmanlı ordusunun Bizans askerine kıyasla sayıca daha üstün olması bir başka deyişle "denizdeki kum gibi sayılamayacak kadar fazla olmasıdır" (Ntekastro, 2008: 12). Yunanca kitaplarda ise Türkler hakkında sıklıkla kullanılan ifadelerin başında iyi savaşçılar olduğunun altı çizilir (Ntekastro, 2008: 16). Bu bir bakıma savaşçı bir toplum olarak gösterilen Türklerin karşısında yenileceklerini bile bile Bizansıılıarın cesurca savaştığı vurgusunun yapılmasıdır. Aslında tüm tarihi 
dönemlerde bu zıt durum, "öteki" karşısında daha cesur olan "ben" vurgusu, tekrarlanan bir kahramanlık göstergesi biçiminde sıkça kullanılan bir metottur. Hangi taraf yeniliyorsa bu "öteki” tarafın ya sayıca daha üstün ya da silahlarının "öteki”ne kıyasla çok daha fazla olmasından kaynaklanır. "Ben"in eksikliğinden ya da güçsüzlüğünden kesinlikle bahsedilmez. Zaten böylesi bir üstünlük karşısında "ben"in cesurca savaşması bile galibin "öteki” olacağı gerçeğini değiştirmeyecektir. Ancak asıl vurgulanmak istenen güçlü "öteki” karşısında mücadeleyi sürdüren "ben"in daha güçlü olduğudur. Neticede "ben” her koşulda kahramandır.

İstanbul'un Fethi Türk kitaplarındaki ifadeyle kan dökülmeden, kimsenin kılına bile dokunulmadan, Bizanslıların da hiçbir direniş göstermeden şehri barışçıl yollarla teslim etmesi olarak betimlenir (Okay, 2010: 40-41). "Artık her tür din ve milletten oluşan insanlar Osmanlı'nın adalet ve huzur şemsiyesi altındadır" (Dursun, 2011: 79). Türkler fethettikleri yerleri barış yoluyla, kan dökülmeden almak ister ancak başka çare bulamazsa savaş yolunu tercih eder (Yeşilçayır, 2012: 108). Oysa Yunan kitaplarında aynı olay örgüsü Türklerin şehre zorla girerek her tür barbarlığı yapması biçiminde karşılık bulur.

Türkler önlerine kim çıkarsa tutsak alıyordu. Kim direnirse olduğu yerde kılıçtan geçiriliyordu. Bazı yerlerde toprak üst üste yığılmış cesetlerden görünmüyordu. Her yaştan insan delirmiş gibi kiliselere saklanmak için akın ediyordu. Ne yazık ki orada bile kurtulamadılar. Kutsal mekânlar ayaklar altında çiğnendi, ibadethanelere atlar sokuldu, ikonlar yakıldı... Her yere kötülük saçımıştı... Çocuklar ağlamaları, kadınların feryatları, tutsaklık, kılıçtan geçirme, tecavüz ne ararsan vardı. Taş taş üstüne bırakılmamıştı (Ntekastro, 2008: 32).

Üstelik İstanbul'un alınması Yunanlılık için ileride özgürlükleri adına savaşacakları 1821 Mora İsyanının fitilini ateşleyen bir öç duygusu da yaratmıştır. "Anlı şanlı İstanbul'un Türklerin eline düşmesiyle kanlı bir ön hazırlık zaten başlamıştı. Barbarların eşi benzeri görülmemiş sefahatinden sonra şehir köleleştirildi. Sonunda da şehri ateşe verip yerle bir ettiler. Bu ateş sönmezden önce Yunanlıların kalplerine intikam ve özgürlüğün ateşi olarak düştü” (Bikos, 1996: 7).

Türkçe kitaplarda Bizans entrikacı, korkak, zoru görünce kaçan, arkadan vuran ve sürekli nifak tohumları saçan bir çıbanbaşıdır (Boyunağa, 2011: 118). "Bizansılı Rumlar Türkler için fitne yatağıdır. Anadolu ve Rumeli topraklarımız arasında devamı şekilde kanayan bir çıbandır, kanatan bir dikendir. Her iki kıtada topraklarımız arasında 
devamlı şekilde bağlantımızı tehlikeye düşüren dost yüzlü hilekâr bir düşmandır" (Boyunağa, 2010: 42-43). Dönem ile ilgili tarihi anlatımlarda dikkat çeken bir diğer husus, Bizans ve Türkler arasındaki mücadelenin etnik çatışmanın ötesinde dini bir çatışma olarak sunulmasıdır. Din olgusu tarihi olay örgüsünde milli duyguları harekete geçirecek etnik unsurların çok önünde kendine yer bulur. Çünkü her iki taraf da dinin ulusun en iyi niteliklerini ön plana çıkarttığını düşünmektedir. Din, ulusun potansiyelinin gerçekleşmesinde bir engel değil, tam tersine en önemli güç olarak görülmektedir (Grigoriadis, 2014: 25). Ulus kimliğinin oluşmasında da din ve milliyetçilik işlev bakımından oldukça önemli iki bağlayıcı unsurdur (Smith, 2000: 125). Özellikle din aynı ulus içinde yaşayan farklı üyeleri bir arada tutan güçlü bir tutkaldır. Bu doğrultudan hareketle Türkçe ve Yunanca kitaplarda yer alan savaşlar etnik olarak Türk-Yunan çatışmasından ziyade Müslüman ve Hıristiyan çatışmasıdır. Türkçe kitaplarda Ortodoks Bizans, Müslüman Türklere karşı Katolik Batıyla işbirliğine girerek İslamiyet'i Hıristiyanlık karşısında güçsüz düşürmek istemektedir. Aslında genel çerçevede bu düşünceyi destekleyen etmenlerin başında, Avrupa tarih yazımında da, Türkler ve geç dönem Osmanlı hakkında sadece olumsuz bir anlayışın olduğunun ve tarihi olayların da bu anlayışa paralel biçimde aktarıldığının düşüncesi gelir (Pesmazoglou, 1995: 187-195). Bununla birlikte Avrupa tarih yazımında Türkler/Osmanlı siyasi ve dini açıdan Avrupa'nın “düşman öteki”sidir. Hıristiyanlar ve Müslümanlar din dışında kültürel çerçevede de Doğu ve Batı arasındaki ayrımın birer sembolleri olarak görülür (Kalın, 2012: 31). Yunanca kitaplarda ise İstanbul'un fethi, İslamiyet'in Hıristiyanlık üzerindeki tehdidi olarak ifade bulur. Ayasofya her iki taraf için de güçlü bir dini semboldür. Türk kitaplarında "Islamiyet ile onurlandırılmış Ayasofya ezan sesinin büyüsüyle inşa edilmesinden bu yana en mutlu günlerini yaşamaktadır" (Dursun, 2011: 80). "Ayasofya'dan yükselen ezan sesleri, yeni bir çağı, kutlu bir dönemi müjdeler...” (Kaplan, 2000: 16). Özellikle Hıristiyanlıkla özdeşleşen Ayasofya'nın Müslümanların eline geçmesi bir Tanrı buyruğudur ve bu kutsal mekân İslam'ın bolluk-bereketiyle yüceltilmiştir (Dursun, 2011: 93). Oysa Yunanca kitaplarda Ayasofya'nın Müslüman Türklerin eline geçmesi tekrar Hıristiyanların eline geçeceği güne kadarki tutulan bir yas dönemidir. "Sus Meryem Ana sus ağlama, zaman geçecek devran dönecek Ayasofya yine bizim olacak" (Grigoriadou, 2005: 140).

Türkler için Bizans, İslam topraklarına göz diken ve İslamiyet için tehlike arz eden ezeli bir düşmandır. "Türkler gelmeden önce, 2 yüzyıla yakın bir zamandır İslam 
âlemine yıldııımlar yağdıran Bizans müdafaasız kalmış Islam topraklarını, obur bir iştahla kemirmeye başlamıştır" (Boyunağa, 2011: 70-72). Milli düşmandan öte dini düşman da görülen Bizans, inanç gereği, hiçbir zaman Türk'ün dostluğuna layık bulunmaz (Dursun, 2011: 45). Aynı ifade Yunan kitaplarında da Türkler için "ezeli düşman" (Nıkolopoulou, 2010: 91) ifadesinin sıklıkla kullanılmasıyla benzer nitelikte karşılık bulur. "Azgın canavarlarla yaşamak Türklerle yaşamaktan daha iyidir" (Arvanitis, 1994: 118). Bu dönemi anlatan Yunan kitaplarında bazen Türklere Pers de denilmektedir. Böylesi bir etnik karmaşanın olması elbette rastlantısal bir hatadan kaynaklanmayıp Bizans'ın M.Ö. V. yüzyıldan beri Asya'dan gelen şiddete karşı mücadele verdiğinin vurgulanmak istenmesiyle açıklanabilir (Arveler, 2007: 194).

Yunanca kitaplarda sıklıkla Türklerin İstanbul'u fethetmesiyle birlikte bir halkanın zincirlerinden sayılan din ve dilin kesintiye uğradığı ve dolayısıyla Antik Yunan mirası sayılan Yunan kültür ışığının da söndüğü dile getirilir. Şehir, barbar Asyalılar karşısında demokrasinin ve bilginin kaynağı sayılan Yunan ruhunu da kaybetmiştir (Ntekastro, 2008: 35). 1453 İstanbul'un fethinden 1829 Yunan Devleti'nin kuruluşuna kadar "Turkokratia" olarak adlandırılan Osmanlı hâkimiyet dönemi tüm Yunanca kitaplarda yasaklar ve baskılarla geçen karanlık bir dönemdir. Türk kitaplarında ifade edilen "barış ve adalet", Yunan kitaplarında Türklerin Hıristiyanlara din değiştirmeleri için eziyet ettiği çoğu zaman da öldürdüğü tutsaklık ve adaletsizlik yıllarıdır. Zaten Batı'nın Doğu ve İslam dünyası algısında İslamiyet, ortaya çıktığı VII. Yüzyıldan itibaren Avrupa için bir "dini ötekidir" (Kalın, 2012: 31). Yunanca kitaplarda İstanbul'un fethinden sonra şehirdeki tüm kiliseleri yıkan ve yenilerinin inşa edilmesine izin vermeyen Türkler (Aleksiou, 1989: 36), Türkçe kitaplarda ise şehrin alınmasından sonra hiç kimsenin inanç özgürlüğüne karışıımadığının ve hiçbir kiliseye dokunulmadığının vurgusunu yapar (Yeşilçayır, 2012: 122). "Biz hoşgörülü bir milletiz. Inançlara saygıı bir milletiz. Bizim topraklarımızda Hıristiyanlar ve Museviler, yüzyıllardır serbestçe ibadetlerini yapmaktadırlar" (Akpınar, 2011: 45).

Sonuç olarak 1453 İstanbul'un Fethi, her iki ülkenin tarih yazımında önemli kabul edilen bir dönemi sembolize eder. İki ülkenin de kendi bakış açısından aynı olayları farkı değerlendirdikleri bu dönemde Türk ve Yunan söylemleri birbirine tamamen zıt ifadeleri içinde barındırır. Fatih Sultan Mehmet'e karşı Konstantinos Paleologos, Ortodoks Bizans'a karşı Müslüman Türk, Fetih'e karşı işgal, bu zıtlıklarda kullanılan örneklemelerdir. Yunanlar bu tarihsel olayı şehrin "apisti" yani inançsızlar 
tarafından işgal edilip yağmalanması şeklinde ifade ederken Türk tarafı da bu topraklara barış ve huzuru götüren bir değer atfeder.

\section{Mora İsyanı mı? Yunan Devrimi mi?}

Kuzey Avrupa ve Asya'da geniş bir alana yayılan Osmanlı hâkimiyet dönemi Osmanlı Devletinin hem ekonomik hem politik alanda sağladığı yükselişi beraberinde getirmiştir. Böylesi güçlü dönemin akabinde İstanbul'un fethi ve Bizans'ın çöküşü ile dönemin büyük ve etkin gücü Osmanlı Devleti olmuştur. Osmanlı'nın bu yükselişi Türkler için topraklarını genişleten güçlü bir imparatorluk içinde hiçbir sıkıntının yaşanmadığı parlak ve şanlı bir dönem olarak ifade edilirken, Yunanlar için çöküşün, baskının, kültürel ve politik gerilemenin var olduğu yıllar biçiminde adlandırılır. Yunan tarih yazımında Osmanlı hâkimiyet dönemi yıllarca köleliğin, korkunun, barbarlığın, Müslüman Türklerin Hıristiyan Yunanlar üzerinde kurduğu etnik ve dini baskının hüküm sürdüğü ve dört bin yıllık Yunan geçmişinin ilk kez yok olma tehlikesiyle karşı karşıya kaldığı en kötü ve en karanlık tarih aralığıdır. Yani Osmanlılar Yunanların kültürel miraslarını ve saf etnik yapılarını bozmakla kalmamış aynı zamanda etnik varoluşlarının temeli sayılan Yunanlılığın devamı bakımından da ciddi bir tehdit oluşturmuşlardır (Frangoudaki ve Dragona, 1997: 352-367). Bu yaklaşım sosyal psikolojide "ben”in tüm olumsuzluklarını “öteki”ne yükleyip "ben”in değerini arttırmayı amaçlayan Durkheim'ın "günah keçisi” teoremi ile açıklanabilir (Schnapper, 2005: 137). Kısacası tarihte Yunan için günah keçisi Osmanlıdır.

Türk tarih yazımında bu döneme ait tarihi veriler Yunan kaynaklarıyla kıyaslandığında neredeyse hiç yoktur ve genel yaklaşım Yunan'ın adaletsiz ve/veya zulüm eden tarafının eleştirilmesidir (Millas, 1998: 258). 1821 Mora İsyanı, (Akşin, 2006) Osmanlı'nın Balkanlardaki ilk toprak kaybını simgelediği için bu dönemle ilgili tarih anlatımlarında suskunluklar hâkimdir. Bilhassa okullarda müfredat içinde yer alan Türk tarih kitaplarında 1821 Mora İsyanı, hem sınırlı bir anlatıma sahiptir hem de ikincil önemde sunulan bölgesel bir direniş olarak gösterilir (Millas, 2005: 97-98). Öte yandan Türk tarihi açısından yenilgi sayılan bu dönemin Türkçe kitaplarda yer bulması Yunan ulusunun özgürleşme hareketinin de resmikabulü anlamına gelir. Böyle bir isyan olayını kolektif belleğe özgürlük zaferi olarak sunmak "biz" algısı için isabetli bir yaklaşım da değildir. Mora İsyanından sonra Osmanlı'da millet-i sadıka olarak anılan 
Rumlar ve Yunanlar devleti içerden çökerten ilk hain millet olarak anılmaya başlanmıştır.

Yunan tarih yazımında ise 1821 Yunan Devrimi/İsyanı ${ }^{5}$ (Clogg, 1992) Osmanlı egemenliğine karşı ulusun uyanışı ve yeniden dirilişini (Rotzokos, 2007) sağlayan ve aynı zamanda Çağdaş Yunan devletinin kuruluşunu simgeleyen münferit bir olaydır. 1821 ayaklanması ile başlayan daha sonra Balkan Savaşları ile devam eden Yunanistan'daki toprak genişlemesi bir bakıma Yunanlıığın da adım adım ilerleyip gelişmesine neden olmuştur. Bu sebeple Yunanistan'daki tarih yazımında özellikle bu dönemi anlatan çalışmaların diğer tarihi dönemlere kıyasla çok daha fazla olması tesadüfî bir sonuç değildir (Frangoudaki\&Dragona (edit), 1997: 367). Dönemi kendisine konu alan Yunanca kitaplarda özellikle Yunan İsyanında yer almış "milli kahramanlar" (Kolokotronis, Papaflessas, Androutsos, Bouboulina vb) ve onların vatan uğruna mücadeleleri detaylı bir biçimde anlatılmaktadır. Bu kahramanlar vatanları için her tür fedakârlığa katlanmış, canla başla, din ve vatan toprağı uğruna savaşmış, tarihin görgü tanıklarıdır. Nitekim benzer örnekler Türkçe kitaplarında da Alparslan, Battal Gazi ve Türk Padişahlarının kahramanlık öykülerinde rastlanılmaktadır. Çünkü her iki ulusun tarih yazımında milli kahramanlar yaratmak ve o kahramanlar üzerinden tarihi kurgular oluşturmak sıkça karşılaşılan bir durumdur. Bu tür tarihi anlatımlar ve milli meseleler ile ilgili kahramanlık hikâyeleri ulusal mitlerin oluşumunda da önemli unsurlardır. Tüm bu unsurlar ulus-devletlerin meşruiyetleri için ideolojik bir mekanizma görevi üstlenir (Klouri, 1995). Elbette bu mekanizmanın oluşumuna hizmet eden diğer önemli faktörler içinde milli bayramlar, marşlar, kahramanlık şiirleri, anma günleri vb. örnekler de gösterilebilir. Toplumsal kimliğin yarattığı "biz" duygusu için kültürel, politik ve tarihi kodlar önemli etmenlerdir (Göka, 2007: 45). Bu minvalde incelendiğinde Yunanistan'da 1821 tarihi, "biz" olgusunu sağlamlaştıran ve bir arada olma duygusunu pekiştiren bir yapıştırıcı görevindedir.

Yunan topraklarındaki Osmanlı hâkimiyet dönemi Yunan tarih yazımında sadece etnik ve dini açıdan yabancıların hâkim olduğu bir devlet idaresi olarak görülmez aynı zamanda baskının, karanlığın, zorbalığın ve sömürünün hatta dildeki değişim ve yabancılaşmanın yaşandığı kayıp yıllar olarak da algıya sunulur

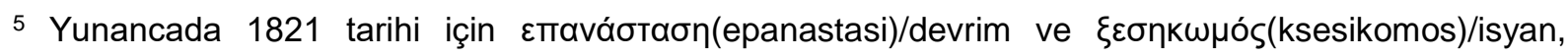
ayaklanma olarak iki terim de kullanılmaktadır.
} 
(Pesmazoglou, 1993). Pek çok tarihi anlatıda Hıristiyanlara din değiştirmek için baskı yapıldığından Yunanca ifadesiyle "Türkleştirmeye"6 çalıştıklarından bahsedilir. Oysa Osmanlı'da devlet örgütlenmesi "millet sistemi" üzerine kuruludur ve bu sisteme göre Osmanlı tebaası Müslim ve Gayrimüslim olarak ikiye ayrılan dini kimlikler üzerinden belirlenir (Dragona\&Birtek, 2006: 21). Buna paralel olarak Yunanlılar da Osmanlı hâkimiyet döneminde Ortodoks kimliğiyle Balkan coğrafyasında varlık göstermişlerdir. Özellikle bu dönemle ilgili Yunanca kitaplarda Yunanlara yapılan zulmün temel kaynağı din olarak verilmektedir. İslam kimliğinin sürekli tehdit ettiği Hıristiyan Yunanlar, 1821 İsyanını ulusal ve dini özgürlüğün kazanımı ile bağdaştıır. Türkçe kitaplarda Osmanlı Devletini kuran Türkler, İslam'ın huzur ve barış ışığını yaymak için diğer topraklar üzerine fetihler düzenlemiş olduklarını belirtirken; Yunanca kitaplarda ise Yunanlar, İsa'nın dinini korumak için Osmanlıya karşı ayaklanmışlardır. Yunanca kitaplarda kilise ve halk sürekli birlik ve beraberlik içindedir. Nitekim ulus-devletlerde dini inanç ve millet ideolojisi bir zincirin ayrılmaz halkalarıdır ve zincirin halkalarından birinin eksik olması ulus ideolojisinin tamamlanamaması anlamına gelir (Brubaker, 2012: 2-20).

Türkiye ve Yunanistan'daki tarihi anlatılarda oluşturulan temel bağlar vatan, bayrak, din ve millet üzerine kuruludur. Yunanca kitaplarda ise din ve millet arasındaki bağı Yunanistan ve Ortodoksluk oluşturur. Bu sebeple her vatansever Yunan aynı zamanda dinine bağı ıyi bir Ortodoks Hıristiyan'dır. Vatan mücadelesinde de din ve vatan kavramları her zaman bir arada, yan yanadır. "Biz Yunanlılar önce dinimiz sonra da vatanımız için savaşmaktayız" (Grigoriadou, 2005: 101). Benzer durum Türkiye örneğinde de farklı değildir. Türk ve Müslüman kimliği tarih anlatımlarında her zaman sıkı ilişki içinde olmuş ve her vatansever Türk aynı zamanda imanlı bir Müslüman olarak düşmana karşı dinini ve vatanını müdafaa etmiştir (Tücan, 2011: 15, 63).

Yunanca kitaplarda 1821 İsyanı, sadece Türklere karşı Yunanlıların sıradan bir başkaldırısı değildir. Bu başkaldııının özünde Hıristiyanların Müslümanlara karşı vermiş olduğu mücadele de yer almaktadır. 1821 Yunan İsyanında vatan ve din uğruna Osmanlıya karşı mücadele edilmesinde, kilise ve devletin birada gösterilmesinin temelinde ulusal kaderin bu bütün içinde var olduğunu kolektif belleğe yerleştirme çabası vardır. Yunan tarihinin babası sayılan Paparrigopoulos da "Yunan-Hıristiyan

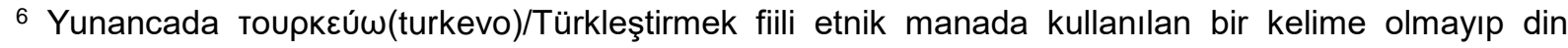
değiştirmek anlamında kullanılmaktadır.
} 
Sentezi" (Paparrigopoulos, 1970) ile Yunanlıık ile Ortodoks Hıristiyanlığı uzlaştırarak dinin millileştirilmesini sağlamıştır (Grigoriadis, 2014: 59). Her iki ülkenin tarihi için din ve millet olgusu ulus-devlet ideolojisini harekete geçiren çift dişli bir mekanizma görevini görür (Skopea, 1988: 205-217). Nitekim Yunan mücadelesinde yer almış en önemli kişilerden biri olan Papaflessas gibi din adamları da din ve vatan özgürlüğü adına Osmanlıya karşı silahlı mücadeleye girmiş ulusal kahramanlardır. Kısaca kilise ve din adamları bu mücadelenin etkin ve önemli aktörleridir. 1821, Yunan tarihi için sadece ulusal değil aynı zamanda dini anlamı olan da bir tarihtir. Bunun en net örneği 1821 Yunan İsyanının başlangıç gününün 25 Mart olarak seçilmesidir. Hz. İsa'nın doğumunu müjdeleyen 25 Mart (Evangelio) Yunan tarihi için de ulusun doğuşunu müjdeleyen seçilmiş/belirlenmiş bir tarihtir. Yunan tarih yazımında $\mathrm{Hz}$. İsa'nın dirilişi ile Yunan ulusunun bağımsızlığı, ulusal mit inşasında ulusun diriliş metaforu olarak kullanılır (Hatzopoulos, 2009: 87-88). 1838 yılında Yunan Kralı Otto'nun kraliyet emriyle 25 Mart gününü, Yunan ulusu için hem milli hem dini bayram olarak resmiyette kabul etmesi (Papatheodorou, 2009: 69) bir bakıma devletin de din ve millet sentezinin kabulünün net örneğini oluşturur. Bu sebeple 25 Mart 1821, Yunan tarih yazımında gerek dini gerek ulusal bir müjdenin tarihsel sembolüdür. Bu sembol Yunan ulusunun doğuşunu simgeleyen 25 Mart 1821 tarihini bir kilise içinde, din adamının elinde tuttuğu Yunan bayrağıyla mücadele kahramanlarını kutsaması biçiminde de tasvir edilmektedir. Bu tür resim örnekleri pek çok okul ve tarih kitaplarında yer alarak hayali ulus mitinin gerçekle özdeşleştirilmesini sağlamış ve kolektif bellekte bu tarz görsellere sahici bir rol vermiştir.

Yunanca kitaplarda 1821 Yunan isyanı özellikle din adamlarının da vatan mücadelesinde etkin rol oynadığı tarihi bir dönemdir. Nitekim bu durum Yunan tarih yazımında din ve millet sentezini pekiştirecek önemli bir örnekleme olarak da kabul edilebilir. Bu dönemle ilgili pek çok tarih anlatısında köye giren Türkler ilk önce kiliseyi ateşe verip sonra da köyün papazını öldürürler. "Türkler önce köyün papazı Kirillos'u kilisenin ağacına astılar sonra da kiliseyi ateşe verdiler" (Arvanitis, 1994: 111). Türkler bu isyan sürecinde genç-yaşı, çocuk-kadın, din adamı demeden Yunanlıları acımasızca öldüren ve merhamet göstermeyen kişiler olarak tasvir edilir. "Türkler $i k i$ yüze yakın isyancıyı diri diri yakmıştı. Kimisini şişten geçirdi, kimisini ateşe attı, kimisini de çengele astı... Larisa metropoliti Dionisios'un da canlı canlı derisini yüzdü. Vücudunun derisini alıp samanla doldurdular. Ölü bedenini önce şehirlerde dolaştırıp 
rezil ettiler sonra da Istanbul'a Sultan'a davullarla zurnalarla yolladılar" (Dedusi, 2010: 25-26).

Şekil 1. Aya Lavra'da Yemin (Theodoros Vrizakis, 1865)

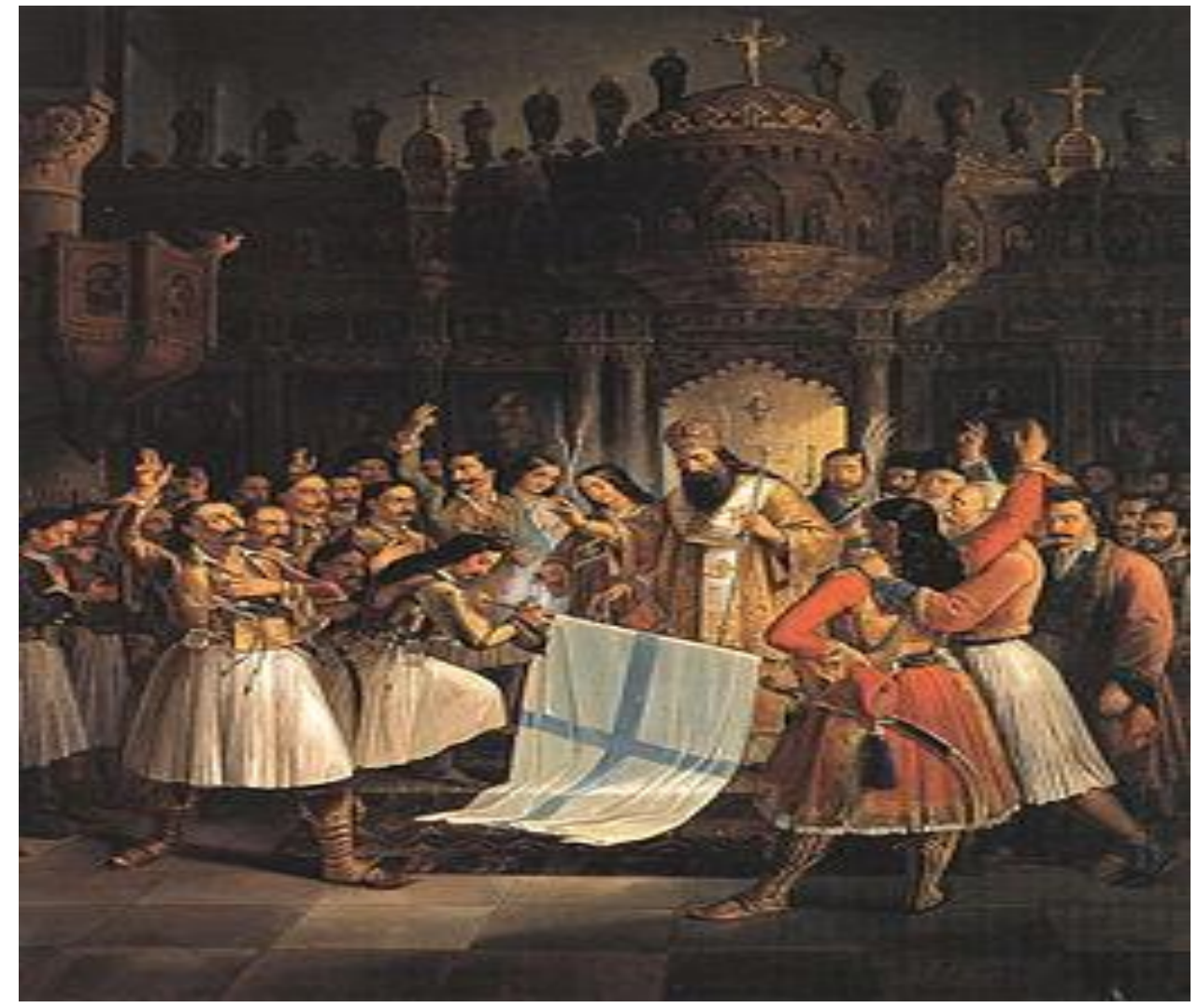

Yunanca kitaplarda Osmanlı hâkimiyet döneminin en belirgin anlatısı Türklerin her yola başvurarak Yunanların dinini değiştirme baskısıdır. Özellikle Hıristiyanlara din değiştirmeleri için her türlü eziyeti yapmaktan çekinmezler. "Hıristiyan gence eziyet etmeye gelen Agarinos (Türk) onu kimi zaman ellerinden kimi zaman da bacaklarından toprağın üstünde bir iki karış kalacak şekilde yukarıya asıyordu. Bazen de altına saman koyup yakıyor ve genci dumana boğuyordu. Onu dövdüğü de oluyordu. Bazen de kılıcının sivri ucuyla tüm vücuduna delikler açıyor ve onu tarifsiz acılara sürüklüyordu. Müslümanlığı reddeden gencin Hıristiyan doğdum Hıristiyan öleceğim lafını duyunca da bıçağı gencin göğsüne güçlüce sapladı" (Madenlidis, 2010: 88,120-212). Oysa buna karşılık Türkçe kitaplarda Osmanlı dönemi herkesin inanç özgürlüğünü rahatça yaşadığı, hiçbir din baskısının olmadığı bir dönem olarak anlatııı. "Düşmanlarımızda ölülerimizi bile parçalayacak bir kin var. Biz imparatorluğun hiçbir kasabasında, köyünde hiçbir işte, dinleri ve milletleri ayrı diye kimseyi hor görmedik ve ayırmadık. Hepimiz Tanrı’nın kuluyuz dedik. Kötülük düşünmedik. Dügünlerimize çağırdık. Dinlerine saygı gösterdik. Asırlarca... Sarayda da Türk olmadıkları halde önemli 
vazifelere getirildiler. Bir de bize yaptıklarına bak! Ah Türklük! Değerini bilebilseydik, bu acı günleri görmez, birbirimizle uğraşıp düşmanlarımızı sevindirmezdik..." (Ünver Oral, 2009: 77). Müslümanlığı seçen Hıristiyanlar ise tamamen kendi istek ve seçimleriyle din değiştirmiş kişilerdir. Genellikle bu tür örnekler Hıristiyan kızların Müslüman erkeklere duyduğu aşk ile neticelenen bir durumdur (Boyunağa, 2011/b: 4346).

Yunanca kitaplarda bu dönemle ilgili tarih anlatılarının temel dayanağı Osmanlı'nın Hıristiyanların eğitimi ile ilgili engellemeleridir. Türkler "cahil, bilgi düşmanı ve her şekilde ilim ateşini söndüren" (Aleksiou, 1981: 31) kişiler olarak tasvir edilir. Bu baskılar karşısında ayaklanan Yunanlar sadece özgürlüklerine değil aynı zamanda bilginin ışığına da sahip olmak için Osmanlıya karşı ayaklanmışlardır. "... vahşi Osmanlı Yunanlıları cahil bırakmıştı. Türkler imparatorluk için yegâne tehlikenin imparatorluk içinde yaşayan kölelerin eğitilmesi olduğunu biliyordu. Oysa bilhassa onlar aldıkları önlemler, kurdukları baskıyla Yunanlıları uyandırıp ayaklanmalarına sebebiyet verdi. Okuma yazmaya meyilli Yunan gençlerinin her yolu deneyerek bilhassa korkutarak eğitimlerini engellediler. Bu sebeple işgalci Türkler Yunan ulusunun yeniden filizlenerek dallanıp budaklanmasını endişeli gözlerle seyrettiler. Ve filizlenen dalları kökünden sökmek için bahaneler aramaya başladılar” (Bikos, 1999: 16-17). Yunan tarihinde Osmanlı döneminde yaşanan bu tür engellemeler ve kısıtlamalar karşısında Yunanların eğitimlerini sürdürebilmek ve dillerini koruyabilmek amacıyla "Gizli Okul" (Angelou, 1997) kurduklarından bahsedilir. Aslında "Gizli Okul"

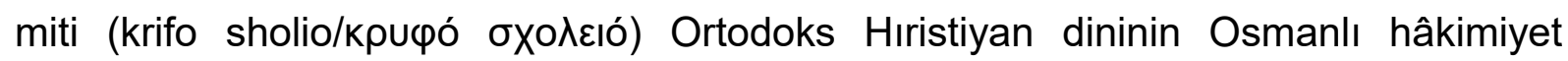
yıllarında Yunan eğitiminin sürdürülmesinde kritik bir rol oynadığının vurgulanması bakımından Yunan milliyetçiliğinde önemli bir ezberdir. IXX. yüzyılda ortaya çıkan milliyetçi anlatıya göre Yunan dil eğitimi, Osmanlı yetkililerinin kısıtlamalarıyla karşılaşmış ve bu sebeple de Yunan dili ve kültürü kilise ve ruhban sınıfının çabalarıyla koruma altına alınmıştır (Grigoriadis, 2014: 65-67). Ancak Osmanlı'da Rum okullarıın faaliyet göstermesi, nitekim Fener Rum Lisesi 1455 'den günümüze eğitim hizmeti veren bir eğitim kurumudur, bu dönemde herhangi bir eğitim yasağının olmadığının da açık bir örneğidir. Yunan tarihinde "Gizli Okul" mitinin oluşturulmasının arkasındaki gerçek, Ortodoks Kilisesinin milliyetçi sicilini ispatlamaya yönelik bir çaba olmasıdır. Bu ulusal mitin görsel belleğe kaydını sağlamaya yönelik Nikolaos Gizis, 1886'da yeraltındaki karanlık bir kilisede mum ışığıyla bir keşiş tarafından yapılan dersin 
resmedildiği "Gizli Okul” görselini hayali olan bir kurumdan çıkararak gerçeğe taşımış ve ulus tahayyülündeki rolünü de daha fazla sağlamlaştırmıştır.

Şekil 2. Gizli Okul (Nikolaos Gizis, 1886)

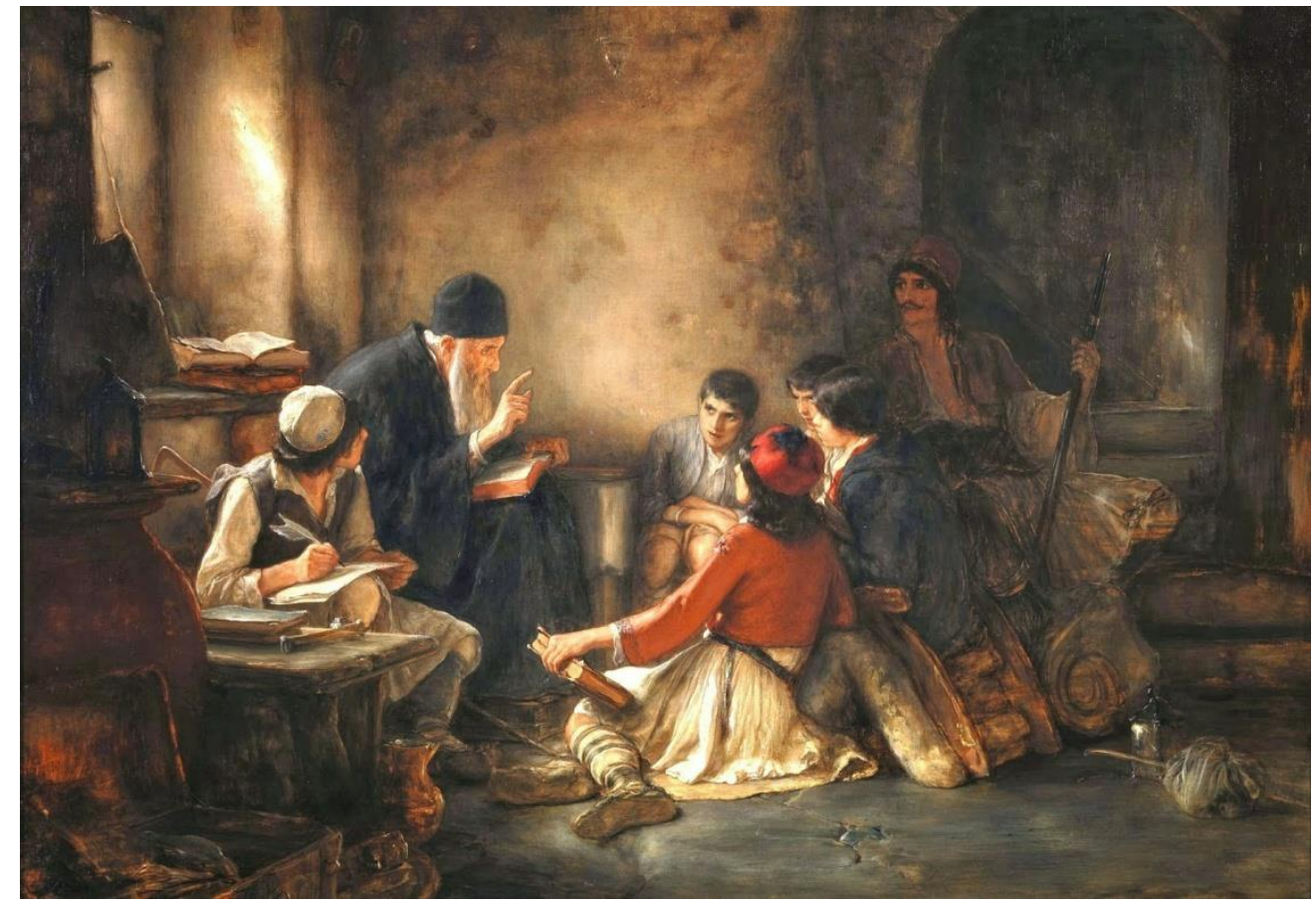

Türkçe ve Yunanca kitaplarda birbirinden farklı tarih anlatımlara sahip bir diğer konu da Osmanlı'da gayrimüslim çocuklarla ilgili devşirme konusudur. Her iki taraf da bu tarihsel olaya kendi bakış açısından yorum getirerek iki farklı anlatı oluşturmuştur.

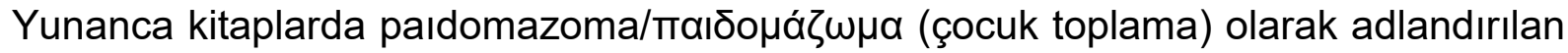
devşirme konusu Osmanlı hâkimiyet döneminde ele alınan temel konuların başında gelir. Devşirme konusu, Türklerin Yunan çocukları üzerinde kurduğu baskı ve şiddetin bir başka örneği olarak tarih anlatılarında yer edinmiştir. Ailelerinden zorla koparılan bu zeki çocuklar Yunanlılığın kanayan bir yarasıdır. "Vahşi zaptiyeler zavallı çocukları ailelerinden zorla alıp bir yere topluyordu. Daha sonra bu çocuklar hiç bilmedikleri uzak memleketlere götürülecek, isimleri, dinleri ve vatanları değiştirilerek Yunanlılara düşman olacak Türk yeniçerileri yapılacaktı. Ne acı ne perişan bir durumdu bu!” (Bikos, 1999: 15). Ulusun büyük çilesi kabul edilen devşirme konusu bir başka ifadeyle Yunanlılık için "kölelik yıllarıdır" (Grigoriadou, 2005: 26). Aynı olay örgüsü Türkçe kitaplarda Yunan anlatısına tamamen zıt bir anlatımla ifade edilir. Devşirme, Hıristiyan aileler için iyi bir hayatın, iyi eğitimin, zenginliğin, şan ve şöhretin garantisidir. Bu nedenden ötürü tüm Hıristiyan aileler devşirme yapılsın diye kendi çocuklarının seçilmesini bir şans olarak görür. "Türkler köylere gelip her kırk evden bir tane çocuğu 
okutmak için ülkelerine götürüyordu. Annem dua et de seni de alsınlar dedi. Türklerin ülkeleri pek güzelmiş. Tanrım beni Türklerin okuluna gönder... Bugün bizim köye devşirmeciler geldi. Koskoca köyden bir tek ben seçildim. Annem benden ayrılacağı için biraz üzgün ama belli etmemeye çalışıyor. Büyük adam olup büyük yerlere geleceğim için seviniyor. Aman oğlum diyor sana söylenenleri iyi öğren. Bizi mahcup etme” (Aydüz, 2011: 45-46). Kısacası Yunanca kitaplarda kökünden sökülme, kaçırılma, vahşet olarak tasvir edilen devşirme, Türkçe kitaplarda rıza ve sessizlik ortamıyla karşılık bulur. Böyle bir karşıtlık Osmanlı vergilendirmesi ile ilgili her iki tarafın anlatılarındaki farklııkta da görülmektedir. Yunanca kitaplarda vergi, Hıristiyanların kendi rızaları dışında zorla alınan bir haraç (Ferousis, 2007: 131) gibi gösterilirken, Türkçe kitaplarda Osmanlı'nın vergi adaletinin simgesi olarak İslam'a geçmeyen Hıristiyanların kendi rızalarıyla devlete ödedikleri paradır. "Müslümanların, Hıristiyanlardan aldığı cizye, Müslüman olmadıkları için ceza olarak alınan bir vergi değildi. Müslümanlar, Hıristiyanları koruma karşılığında bu parayı alıyordu” (Boyunağa, 2011: 41).

1821 Mora İsyanı ve bu sürece kadar Yunan topraklarında Osmanlı hâkimiyet dönemi, her iki ulusun farklı değerlendirmeleri ve bakış açısıyla yorumlanan tarihi anlatılara sahiptir. Bir başka ifadeyle "ben" ve "öteki” arasında yaşanan en zıt tarihi dönemdir. Bu tarihi dönem anlatılarında da Türkler ve Yunanlar yine İslamiyet ve Hıristiyanlık karşılaştırılmasının sıklıkla yapıldığı iki ulus olarak resmedilir. Yunanlar için yeni bir ulusal başlangıç olan 1821, Yunanların en şanlı, en zirve tarihi sembolüdür. Türkler açısından ise Balkanlardaki ilk toprak kaybıdır. Bu nedenle Türk tarih anlatılarında 1821 Mora İsyanı, Yunan tarih anlatılarına kıyasla ya çok azdır ya da hiç yoktur. Osmanlı Devletinin adaletli din ve devlet düzenine isyan ile karşı çıkan Yunanlar sonraki süreçte hain ulus olarak anılmaya başlanacaktır. Türkiye ve Yunanistan arasındaki "tarihi öteki" kavramını başlatan 1821, iki ulusun birbirlerini düşman olarak kabul etmesine sebep olan iki farklı anlayışın da birer temsilidir. Ulus-devlet sürecini 1821 yılında Türklere karşı vermiş oldukları mücadele ile başlatan Yunanlar, Türk tarihinde ise 1821 isyanı ile Osmanlının içeriden yıkımını sağlayan iç düşman olarak kabul edilecektir. 


\section{Kurtuluş Savaşı mı? Küçük Asya Felaketi mi?}

1821 Yunan İsyanı nicelik ve nitelik bakımından ufak fakat bağımsız bir Yunan Devletinin kurulmasını sağlamıştı. Kurulan devletin yeni kimliği nasyonal homojenlik ilkesine dayalı, milli bilincin gelişmesine hizmet eden ve devletin korunmasını amaçlayan temel inanç üzerine kuruluydu. Ancak bu yeni kurulan devletin sahip olduğu coğrafya sınırları içinde din, dil ve kültür bağlamındaki heterojen yapı devletin kendi sınırları içinde mücadele etmesi gereken önemli bir problem olarak kendisini gösterdi. Bu problemle baş etmek ve merkez bir yönetim tahsis etmek için devletin temel işlevsel çarkları ulusal ordunun ve halkın eğitimi üzerine kuruldu. Böylece Yunan devleti zorunlu tuttuğu eğitim sayesinde sahip olduğu mevcut nüfusun dilsel bağlamda homojen bir yapıya bürünmesini de sağladı (Kitromilidis, 2012: 75-87). Özellikle Yunanistan'daki eğitim sistemi her dönem ulusal kimliğin oluşumunda ve gelişiminde belirleyici bir rol oynamıştır (Frangoudaki ve Dragona, 1997: 15-34). Nitekim Yunanistan'da bu dilsel homojenlik ve yeni eğitim sistemi Megali İdea'nın devletin yeni siyasal düzeninde kabul görmesini de kolaylaştırmıştır.

Modern Yunan devletinin kuruluşundan sonraki süreçte topraklarını ve hâkimiyetini genişleten Yunanistan karşısında Osmanlı devleti "hasta adam" nitelendirmesiyle toprak kaybetmeye ve gerileme dönemine girmişti. Yunan devletinin merkez ideolojisi olan Megali İdea fikir mirası, I. Dünya Savaşı akabinde Yunan ordusunu İzmir ve Küçük Asya topraklarına askeri çıkarma yapması için itici bir güç oluşturdu. İki kıta beş deniz politik hesabıyla Megali İdea, Yunanistan'ı başta bir zafer gibi görünen ama sonrasında "Küçük Asya Bozgunu"7 olarak adlandırılan yeni bir felakete sürükledi. Varılan bu noktada 1922, Yunanlar için Megali İdea'nın gerçek manada sona erdiği bir hayal kırıkığı olarak kabul edilmektedir. Küçük Asya Bozgunu sonrasında yaşanan nüfus mübadelesi ile pek çok Yunan, Anadolu topraklarından göç etmek zorunda kaldı/bırakıldı. 1922 Küçük Asya Bozgunu, Yunan tarih yazımında politik, ekonomik, askeri ve toplumsal anlamda Yunanlılı̆ın acı yenilgisi olarak kabul gören tarihi bir kesit olarak hatırlanmaktadır. Bu hezimet Yunan kolektif belleğinde sadece askeri bir yenilgi olarak değil aynı zamanda Küçük Asya'da var olan Yunanların köklerinden koparılması temsiliyle manevi bir yenilgi olarak da yer edinmiştir.

\footnotetext{
71922 Küçük Asya Bozgunu Yunan tarih terminolojisinde Küçük Asya Felaketi/ Mıkrasiatiki Katastrofi (Мıкрабıатıкń Катабтрофи́i olarak kullanılmaktadır.
} 
Türk tarih yazımında ise 1922, Kurtuluş Savaşında işgalci güçlere karşı verilen vatan müdafaası olarak sembolize edilir. Türkler ve Yunanların bu tarihi kesişmede birbirlerine karşı verdikleri mücadelenin galibi "Yunanılıarı denize döken" (Oral, 2009: 214) Türk tarafıdır. Ancak 1922, Türk kolektif belleğinde sadece yurdun bağımsızığı olarak değil aynı zamanda Sultan idaresinden demokrasiye geçen Türkiye Cumhuriyetinin rejim değişikliği olarak da kabul gören önemli bir tarihtir. Böylesi bir sonuç, Doğu Asya kimliğinden yönünü Batıya dönmüş yeni bir ulusun, özünde Avrupa dünyasına girişini onaylayan bir durumu da beraberinde getirmiştir. 1922, Türkler için, yeni kurulan Türkiye Cumhuriyeti ile Türk milli kimliğini oluşturan önemli bir başlangıç noktası sayılmaktadır.

1922, Türkiye ve Yunanistan tarih algısında ak ve kara gibi zıt iki renk gibidir. Türk tarih yazımında "ulusal bağımsızlık", Yunan tarih yazımında "ulusal felaket" tanımlamasıyla karşııık bulan 1922 aynı zamanda Türkiye Cumhuriyetinin kurulması ve Anadolu'da Yunanlıı̆ın sona ermesi biçimiyle de iki farklı algıya da sahiptir. Dönemin İstanbul Ortodoks Patriği Meletios'un başbakan Venizelos'a 7 Eylül 1922'de gönderdiği mektupta da belirttiği gibi 1922 Küçük Asya Felaketi ile "Yunanlılık kimsenin kurtaramayacağı çok derin bir çukura düşmüş ve asırlardır üzerinde yaşadığı vatanından kovulmuştur" (Anagnostopoulou, 1998: 11). Türk ve Yunan ulusal tarihinde yüklendiği mana itibariyle bir dönüm noktası sayılan Anadolu, Yunanlılar için kaybedilen; Türkler için kurtarılan ulus topraklarıdır. Her iki taraf da Küçük Asya/Anadolu topraklarındaki varlığını asırlardır bu topraklar üzerinde yaşayan atalarına bağlar. Kurulan bu tarihi köprü, ulus-devletler için önemli addedilen "süreklilik" için de önemlidir (Smith, 2001: 83-85). Bu nedenle her iki tarafın atalarından miras kalan Küçük Asya/Anadolu, ya Yunana ait olan toprak parçasıdır ya da bir Türk yurdudur. Karşılıklı çaba, bu topraklarda kimin daha önce kaldığını ispatlamak üzerine kuruludur. "Nihayetinde Küçük Asya topraklarında Yunanlılar, Antik dönemden beri ezeli yaşamışlardır. Oysa Türkler bu tarihi kıstaslara göre sonradan bu topraklara gelmiştir" (Nikolopoulou, 2010: 95). Bu tarihi ispat, Yunan tarihçi Paparrigopoulos'un Çağdaş Yunan'ı Antik Yunan'a bağladığı tarihi anlayıştan beslenir. Paparrigopoulos'a göre bugünkü Yunanlılar Antik Yunan torunlarıdır ve dil, coğrafya, ortak kültür bakımından onların birer devamıdır. Aynı tarihi ispat, 1923 yılında kurulan yeni Türkiye Cumhuriyeti'nin milli kimlik oluşturmak adına 1930'lu yılların ilk döneminde geliştirdiği Türk Tarih Tezi ve Güneş Dil Teorisi ile paralellik de göstermektedir. Bu teoriler 
ışığında Türkler dil, coğrafya ve kültür olarak insan uygarlığının en eski milletlerinden biridir. Aslında Türk ve Yunan tarih tezleri birbirine benzerlik bakımından ulusun hayal edilen bir cemaat olduğunu da ispatlar niteliktedir (Anderson, 2009: 22). Toplumsal geçmiş ve ortak ulus mitleri üzerine dayalı bir sistem Türkiye ve Yunanistan'ın ulusdevlet süreçlerinde rastlanan bir durumdur. Uluslar geçmişteki etnik sembollere, hatıralara, mitlere ve değerlere, önceki kuşaklardan miras aldıkları kutsal geleneklere intiyaç duyar ve bundan beslenir (Özkııımlı ve Sofos, 2013: 6).

1922, Türk ve Yunan tarihinde değişen iki farklı sayfadır. Yunanlar için değişen sayfa özünde bir kapanış iken Türkler için yepyeni bir sayfanın başlamasıdır. Birbirine "son" ve "başlangıç" gibi iki tezat olguyla bağlanan bu tarih, her iki ülkenin döneme ait tarih anlatılarında da tezatlık/farklıık gösterir. 1922, Yunanlılığın büyük ulus rüyasını ulus kâbusuna çevirmiş ve uzun yıllar bu kâbustan uyanamamış bir milletin tarihi olarak takvimde yer alırken, Türkler bu tarih ile ulusal tarihlerini başlatmış ve ulusun ilerlemesi ve gelişmesi yönünde yeni bir tarihi başlangıç yapmıştır. Türk tarih yazımında İzmir'in Yunanlar tarafından işgali ve Yunanların Rumlar ile işbirliği içinde olması Türk kolektif belleğinde derin iki iz bırakır. Yunanların Anadolu topraklarındaki mezalimi ve Rumların "iç düşman" olarak ihaneti, ulusal hafızanın hiçbir zaman unutamadığı kötü hatıralardır. "Yunanlılar geliyorlarmıs. Hem de etrafı yakıp yıkarak... Rumlar da onlara kılavuzluk ediyormuş" (Teres, 2010: 11). Her iki olumsuz hatıra daha sonra iki ülke arasında yaşanan tarihi süreçlerde çözümsüz problemleri beraberinde getirmiş ve iki ülke ilişkilerini dönem dönem çıkmaza sokmuştur.

Türkçe kitaplarda pek çok yazılı ve görsel metin, 1919-1922 yılları arasında Yunanların işgal ettiği Anadolu topraklarındaki mezalimi anlatan konulardan oluşur. "Yunanlar İmirlilere zulmetmeye çoktan başlamışlardı. Çocuklar dövülüyor, masum kadınlar zevk için süngüleniyordu." (Yavuz Bahadıroğlu, 2009: 26) "Yunan askerleri yaşlı kadınlara eziyet ediyor, daha bir yaşını bile doldurmamış bebekler üstünde nişan talimi yapıyordu" (Bahadıroğlu, 2008: 10).

Gördüm ki Yunan köye girmiş. Kahkahalar atarak yakıyor, yıkıyor, öldürüyorlar. Köyü dolaşırken feci şeyler gördüm. Bir kadının karnını süngülerle parçalıyorlar, bir çocuğu kurşunluyorlardı. Yürümeye başlamış bir bebeği yerde süngüleyen bir Yunan askerini görünce tüfeğini tutmak istedim. Yunan askerleri köyde tek canlı bırakmamak için gelmiş olmalılardı. Girdikleri evleri ateşe vermişlerdi. Ayrıca köyde unutulan iki çocuk tanınmayacak, kandan görünmeyecek 
durumda idiler. Sanki Yunan askerleri bütün intikam ateşlerini bu iki Türk çocuğunu süngülerle delik deşik ederek söndürmüşlerdi (Oral, 2009: 118, 119, 189).

Bu döneme ait tarih anlatımlarında Yunan bir dış düşman olarak sunulur. Zorla topraklarına giren ve topraklarını kana bulayan Yunanların Anadolu'yu işgal etmesi Yunan tarih anlatısında ise atalarından miras kalan Anadolu topraklarını ve oradaki din kardeşlerini "barbarların Türkleştirdiği ve köleleştirdiği toprakları" (Grigoriadou, 2005: 26) kurtarmak amacıyla düzenlenmiş bir fetihtir. Yunan tarihinde ataları nezdinde kutsal bir ödev sayılan ve kayıp topraklar olarak görülen Anadolu topraklarının geri alınmasının önemi, Yunan tarihinde ulus ülküsü sayılan Megali İdea'nın da fiilen uygulanması anlamına gelmektedir. Bu nedenle Türkler için İstanbul'un fethi neyse Yunanlılar için de Anadolu'nun alınması aynı değer ve önemdedir. Her iki tarihi olay da iki ulusun kimliğinin oluşması için gerekli olan tarihi kodlardır. Bu nedenle Yunan tarih yazımı Anadolu topraklarını işgal olarak değil fetih olarak nitelendirir. Aynı paralel görüş içinde Türkler de İstanbul'u işgal değil fethetmişlerdir.

Çok eski zamanlarda topraklarımıza l̇onya denilmekteydi. Burada Yunanlılar yaşıyordu. Bu topraklara sahip olmak bizim hakkımızdır. Bu topraklar bizim ata mirasımızdır. Ege sahilleri bizimdir. Ege ovaları, İstanbul, Aya Sofia bizimdir. Eğer bu toprakları bu gâvurların ${ }^{8}$ eline bırakırsak atalarımızın kemikleri sızlar (Nikolopoulou, 2010: 24,91).

Yunanca kitaplarda bu döneme ait tarih anlatılarında Büyük Taarruz, Türklerin İzmir'e girmesi ve sonrasındaki nüfus mübadelesi yer almaktadır. 1922, Yunan kolektif belleğine kaybeden ve vatanı gördüğü Anadolu'dan göç eden acılı bir ulus kavramını hatırlatır. Bu döneme ait tüm hatırlananlar özlemler, acılar, yıkımlar, hayal kırıklıkları ve ölümlerdir. Bu geçmişe özlem duygusu ulusun yaralı belleğinde var olma sebebidir. Bu yaralı belleği ona kederden duyduğu bir haz da getirir. Üzüldüğü geçmiş onu bir manada bugüne de bağlayan bir tezatlık duygusudur. Bu acıları hatırlamak ya da daima belleğinde yaşatmak toplumu bir arada tutan ve kaynaştıran bir bağlayıcı zincirdir (Papatheodorou, 2009: 69). Yunanca kitaplarda, Türklerin İzmir'e girmesi ile

\footnotetext{
${ }^{8}$ Her iki taraf da tarihi anlatılarında "ötekini" inançsızlıkla itham eder. Türkçede gâvur olan kelime Yunancada da aynı anlamı taşıyan ó́mıбтoৎ/apistos ile verilmektedir. Müslüman olmayanlar için kullanılan bu ifade Hıristiyan olmayanlar için de benzer şekilde kullanılmaktadır.
} 
Türkçe kitaplarda Yunanlıların İzmir'i işgali aynı tiyatro oyunun farklı aktörlerce yeniden oynanması gibidir. Aynı olaylar kişi ve zaman farklıı̆̆ıyla yeniden anlatılır.

Türkler girdiği Yunan köylerinde yolarına çıkan tüm Hıristiyanları kendi ırkının tüm barbarlığıyla öldürdü. Bazı Türkler üzerlerinde taş, sopa ve demirden çubuklar taşıyordu. Kimilerinde balta ve bıçak vardı. Türk çocukları bile bu yağma ve katliama katılmıştı (Nikolopoulou, 2010: 171,183).

Yürümekten ayaklarımız şişmişti. Üstelik susuzluktan da ölüyorduk. Gittiğimiz yerde pek çok kuyu olmasına rağmen su içmememize bile izin vermedi Türkler. Üzerimizdekilerin hepsini çaldılar. Para, yüzük ne varsa. Her sabah bizi meydana götürüyorlardı ve askerler de bizi bu insan pazarından satın alıyordu (Nikolopoulou, 1991: 130).

Şekil 3. İzmir'in işgali (Vittorio Pisani, 1919)

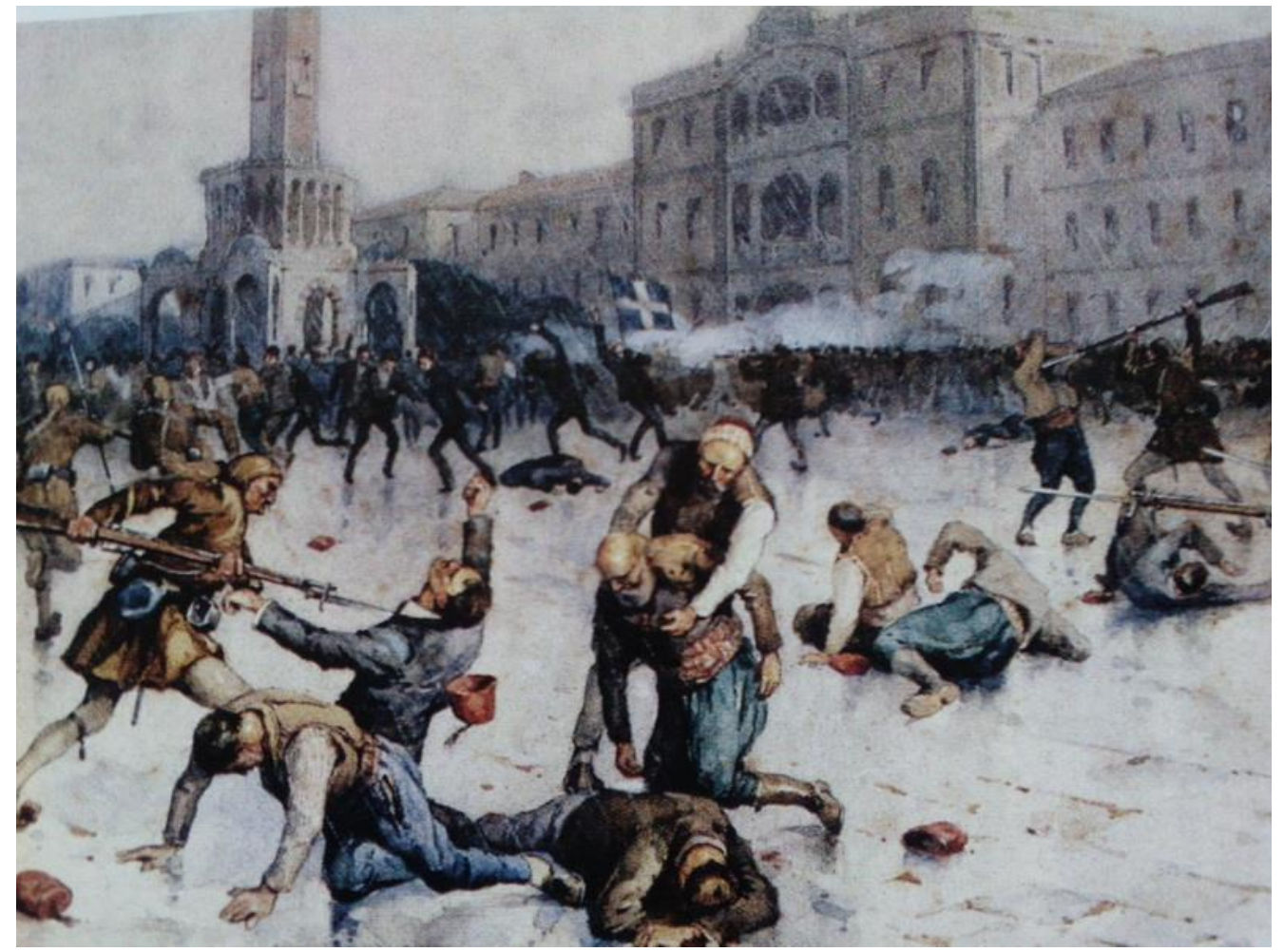

Türkiye ve Yunanistan'ın farklı algıladığı bu tarihi dönemde kullandığı ortak malzeme düşman gördüğü "öteki”nin kutsalına yapılan hakarettir. Yunanlar ilk kez İzmir'in işgali ile girdiği Türk topraklarında önce kutsal mabetlere zarar verir ya da din büyüklerini aşağılayacak hareketlerde bulunur. Aynı durum Yunan tarih anlatısında, Türklerin girdiği Yunan köylerinde de benzer eylemi gerçekleştirdiğine dair ifadelerin kullanılmasıyla karşılık gösterir. Türk kitaplarında İzmir'in Yunanlar tarafından işgali 
dine ve vatana yapılan yeni bir Haçlı ordusu tehdidi olarak sunulmaktadır. Yunan askeri Türklerin kutsal saydığı her şeyi ayaklar altına alır ve hakaret eder. "Yunan askerler raflara saldırıyorlar. Ellerine geçen Kuran-ı Kerimleri kucak kucak pencereden dışarı attılar" (Bahadıroğlu, 2009: 39-40). "Yunanlılar bir Hoca Efendi'ye Hıristiyanlığı kabul etmesini söylediler. Hoca reddedince, başındaki sarı̆̆ın beziyle boğdular" (Bahadıroğlu, 2009: s. 33). Benzer bir durum Yunan tarih anlatılarında da İzmir'e giren Türk askerleri için geçerlidir. "Türkler papazların hepsini kılıçtan geçirdiler ve Despotu açtıkları derin çukura diri diri gömdüler” (Mousiopolou, 1992: 52). "Azgın Türk kalabalık eline geçirdiği despota işkence ediyordu. Onu aralarına almış yuhalıyor, suratına tükürüyor, tekme tokat dövüyorlardı. Yaralarından kanlar akıyordu. Onu dizlerinin üstüne çökertip defalarca kamçıladılar. Asya steplerinde yaşamış eski vahşi atalarından miras aldıkları küfürleri, tekmeleri despota savuruyorlardı" (Nıkolopoulou, 2010: 183). Özellikle Türkiye ve Yunanistan için her dönemi içine alan tarih anlatılarında kutsala yapılan tehdit ve hakaret üzerinden "öteki" yaratmak çok sık rastlanılan bir durumdur. Din kutsalı üzerinden gerçekleşen anlatımların "öteki" imajında yarattığı düşman algısı diğer sosyal olaylarla ilişkilendirilen "düşman öteki" imajından çok daha kuvvetlidir. Örneğin “öteki” gruptan biri, "ben” grubuna ait yüzlerce sıradan insanı öldürdüğünde "öteki” için geliştirilen tepki kızgınlık ve öfke duygularıdır. Ancak "öteki" "ben" grubundan bir tane bile olsa din adamı (papaz ya da hoca) öldürdüğünde tepki infial yaratan duygulara dönüşür. Nitekim ev yakan düşman, cami/kilise gibi kutsal mekânları yakan düşmandan daha az tepki çeker. "Yunanlılar masum yavruları kılıçtan geçiriyor, halkı camilere doldurup camiyi ateşe veriyordu" (Bahadıroğlu, 2009/b: 27).

Türk ve Yunan kitaplarında 1922 ile ilgili tüm tarihi anlatılar savaş dönemini içermesinden ötürü "öteki” ve "ben” arasında geçen karşılaştırma iyi-kötü karşılaştırmasından çok, dost-düşman karşılaştırmasıyla belirginleştirilir. Bu ayrım savaşçı toplumların kötü gördüğü “öteki”ni düşman olarak tanımlaması ile aynı doğrultuda düşünülebilir (Mennell, 1994: 175-197). Kısaca savaş olan bir ortamda "kötü öteki” yoktur "düşman öteki” vardır. Özellikle savaş ortamında "öteki” ile ilgili ön yargıların pekiştirilmesi ve ulusun ortak hafızasına alması çok daha kolay gerçekleşir. Yani, savaş ortamında eğer "biz"im dışımızda bir "yabancı/öteki" varsa mutlaka düşmandır (Abatzapoulou, 1998: 249-250). Nitekim 1922 tarihi döneminde de her iki ulus diğerini grubun (bizim) dışına alarak düşmanını belirlemiştir. Bu düşman algısı 
Şekil 4. Osmanlı Askerleri ve Ortodoks Papazı (Petros Bikos, 2009: 26)

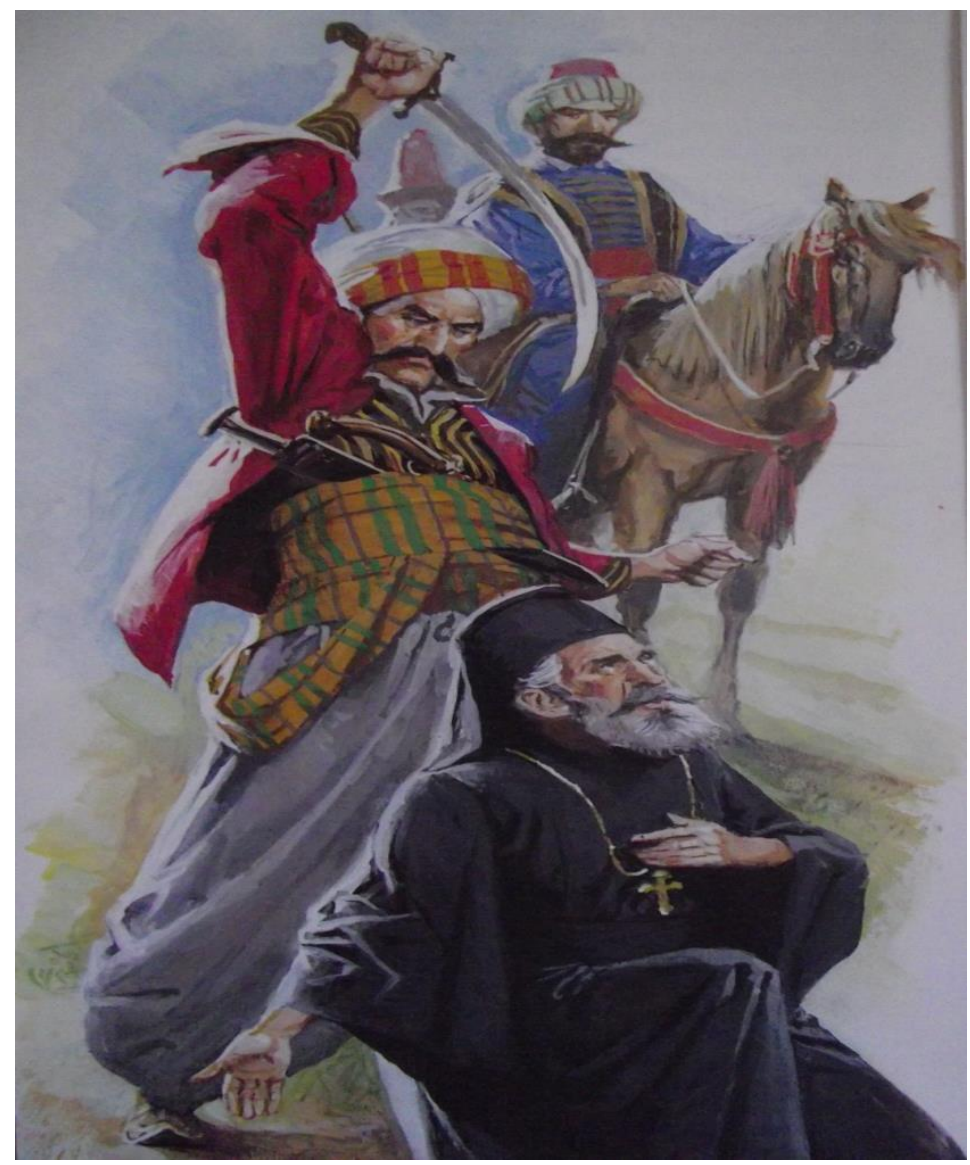

etrafında gelişen tüm olaylar da ulusal kimlik için geçerli olan ve "biz"i bir arada tutacak algıyı oluşturmada önemli bir mekanizma görevini görür. Her iki taraf için "öteki” bir anlamda benzer olayların yaşanması bakımından görüntünün tam net olmadığı sudaki akis gibidir.

\section{Sonuç}

Türkiye ve Yunanistan'daki tarih yazımında her iki ulus birbirleriyle hemen hemen aynı kodları izleyerek kendi tarih anlatısını oluşturmuştur. Bu kodların başında iki ulusun kendi milli propagandasını "öteki" karşısında daha kuvvetli tutma gayreti vardır. "Öteki” ile arasındaki tarihi ilişkide hiçbir empatiye yer verilmeksizin olaylar "ben" süzgecinden geçirilerek yorumlanır. Böylesi bir çaba da beraberinde kendi ulusunun ötekiler karşısındaki üstünlüğünü iki taraf açısından uzaklaştırıcı mesafelere dönüştürür. Bu nedenle Türk-Yunan Tarihinde ortak gözlem, iki tarafın tarih anlatısında da "ben" ve "öteki" arasındaki keskin uçurumun varlığıdır. Türkiye ve Yunanistan ulus tarihini düşman gördüğü öteki üzerine kurduğu için tarih anlatısının neredeyse büyük 
kısmında mücadele ettiği "öteki"ler bulunur. Döneme göre değişim gösteren bu “öteki”ler arasında öncelik Türk için Yunan'a; Yunan içinse Türk'e aittir. Böylesi bir mekanizmanın oluşumu ulus-devlet süreçlerinde oluşturulan ulus kimliğinin her iki ulus tarafından "öteki” ile ilişkilendirilmesi olarak açıklanabilir.

Tarihi geçmişin aydınlatılmasından ziyade gelecek için bir ders niteliğinde gören Türk ve Yunan tarih öğretimi iki ulusu geçmişteki bu ortak tarihi mirasından ötürü her an kendisine zarar vermeyi bekleyen bir role de büründürür. Bu doğrultuda tüm tarih anlatıları "öteki" üzerinden "bana" yapılan bir uyarı niteliğindedir. Ezeli düşman algısı, iki ulusun tarih anlatımında unutulmaması gereken bir detay olarak sürekli hatırlatıır. "Ben" hep üstün ve yenilmez olandır. "Öteki" ise hep sorun çıkarandır. Sterotipler ve ön yargıların en çok görüldüğü tarih anlatılarında bazen tarihi olayın kendisinden çok bu olayın nasıl anlatılmak istenildiği önem kazanmaktadır. Düşman etrafında birlik kurulması için güçlü ve olumsuz imajların yaratılması gerekir. Bu olumsuz imajlar etrafında "biz" birliğinin kurulması ulus kimliğinin oluşmasında oldukça etkin bir görev üstlenir. Bu nedenle Türk ve Yunan tarih anlatılarında birlik mesajları "düşman öteki”nin en kolay oluşturulduğu savaş dönemlerinde verilir.

Ulus tarihlerini birbirinin tam zıt yönünde kuran Türkiye ve Yunanistan için farklı tarih anlatısı elbette beklenenin dışında bir şaşırtıcılığa sahip değildir. "Öteki" ile ilgili imaj çalışmalarında önemli olan da bu imajların "neler?" olduklarından çok "neden?" olduklarına verilen cevapların bulunmasıdır. Nitekim Türkiye ve Yunanistan arasındaki bu tarih anlatılarındaki farklılıkların temelinde de iki ulusun, tarihi algılamasındaki dönemsel koşulları ve bu koşulların ulus bilincinde yarattığı sonuçları incelenip irdelenmelidir. 


\section{Kaynakça}

Abatzapoulou, F. (1998). O Allos en Diogmo. I İkona tou Evraıou sti logotehnia. Zitimata istorias kaı mithoplasias. Atina: Themelio.

Akşin, S. (2006). Ana çizgileriyle Türkiye'nin yakın tarihi (1789-1980), Ankara: İmaj.

Anagnostopoulou, S. (1998). Mikra Asia 19 aına -1919 ol Ellinorthodokses

Koınotites apo to Millet ton Romion sto Elliniko Ethnos, Athina: Ellinika Grammata.

Anderson, B. (2009). Hayali cemaatler, İstanbul: Metis.

Angelou, A. (1997). To Krifo Sholeı: Hroniko Enos Mithou, Athina: Estia.

Arveler, E. (2007). Politismos kaı Ellinismos, Athina: Kastanioti.

Barthes, R. (2012). Göstergebilimsel serüven, İstanbul: Yapı Kredi.

Bilgin, N. (1994). Sosyal bilimlerin kavşağında kimlik sorunu. İzmir: Ege.

Bilginer, E. (2012). Recent debates on Greek history textbooks: The case of contemporary history texbookf for 6th grades by Maria Repousi. (Yayınlanmamış Yüksek Lisans Tezi). İstanbul: Bilgi Üniversitesi Sosyal Bilimler Enstitüsü Uluslar arası Iliş̧kiler Anabilim Dalı.

Bodenhausen, G.V., Sheppard L.A., Kramer, G.P. (1994). Negative affect and social judgment: The differential impact of anger and sadness. European Journal of Social Psychology, Special Issue: Affect in Social Judgments and Cognition, $24: 1$, , o. 45-62.

Brubaker, R. (2012). Religion and nationalism: Four approaches. Nation and Nationalism, Cilt: 18, ss. 2-20.

Carr, Edward H. (2013). Tarih Nedir?. İstanbul: İletişim

Copeaux E. (1998). Türk kimlik söyleminin topografyası ve kronografisi, tarih eğitimi ve tarihte "öteki" sorunu. II. Uluslararası Tarih Kongresi. İstanbul: Tarih Vakfı Yurt Yayınları, ss. 70-84.

Copeaux, E. (1998). Türk tarih tezinden türk islam sentezine. İstanbul: Tarih Vakfı Yurt. Clogg, R. (1992). Modern Yunanistan tarihi. İstanbul: İletişim. 
Dragona, Th. \& Birtek, F. (2006), Ellada kaı Tourkia. Politis kaı Ethnos-Kratos. Athina: Aleksandreia.

Frangoudaki, A. \& Dragona, Th. (1997), Ti eınaı i patrida mas; Ethnikismos stin Ekpaıdeusi. Athina: Aleksandria.

Göka, E. (2007). İnsan kısım kısım: toplumlar, zihniyetler, kimlikler. Ankara: Aşina.

Grigoriadis, I.N. (2014) kutsal sentez, yunan ve Türk milliyetçiliğine dini aşılamak. İstanbul: Koç Üniversitesi.

Güvenç, B. (1998). Tarihi perspektifte kimlik sorunu özdeşimlerini belirleyen bazı etkenler, tarih eğitimi ve tarihte "öteki" sorunu. II. Uluslararası Tarih Kongresi. İstanbul: Tarih Vakfı Yurt, ss. 23-29.

Hatzopoulos, M. (2009). From resurrection to insurrection: sacred myths, motifs and symbols in the Greek war independence, Roderick Beaton-David Ricks (edit), The Making of Modern Greece: Nationalism, Romanticism and the Uses of the Past. Farnham, Surrey: Ashgate.

Kalın, İ. (2012). İslam kaı Disi. Athina: Papazisi.

Kitromilidis, P. (2012). Noeres koınotites kaı ol aparhes tou ethnikou zitimatos sta Valkania. Thanos Veremis (edit), Ethniki Tautotita kaı Ethnikismos stin Neoteri Ellada. Athina: MiET

Klouri, Ch. (1995). Mithoi kaı simvola mias ethnikis epeteiou, Paniyirikos Logos ston episimo eortasmo tis 25 Martiou. Komotini:

http://lesxianagnosiskor.blogspot.com/2009/12/blog-post 08.html. Erişim tarihi: 18 Şubat 2015).

Millas, H. (2005). Öteki ve kimlik. İstanbul: İletişim.

Millas, İ. (2005). İkones Ellinon kaı Tourkon. Sholika Vivlia, İstoriografia Logotehnia kaı Ethnika Stereotipa. Athina: Aleksandreıa.

Millas, İ. (1998). Türk ders kitaplarında "Yunanlılar": Bütünleştirici bir yaklaşım. Tarih ğğitimi ve karihte "Öteki” Sorunu, II. Uluslararası Tarih Kongresi. İstanbul: Tarih Vakfı Yurt, ss. 254-265.

Oıкоvouou, İ. (1992). İsagogi stin Singritiki Stereotipologia ton Ethnikon Haraktiristikon sti Logotehnia. Thessaloniki: Unıversity Studio. 
Papatheodorou, G. (2009). Romantika Pepromena. O Aristotelis Valaoritis os "ethnikos poritis". Athina: Vivliorama.

Özkırımlı, U. \& Sofos, S. (2013). Yunanistan ve Türkiye'de milliyetçilik. İstanbul: Bilgi Üniversitesi.

Özsüer, E. (2012). Türk-Yunan ilişkilerindeki "biz" ve "öteki” önyargıların dinamikleri. Avrasya Incelemeleri Dergisi (AVID), Sayı: 1/2, ss. 269-309.

Özsüer, E. (2015). Ellinika kaı Tourkıka vivlia mithoplasias gıa paıdiko koıno: eıkones kaı proslipseıs. (Yayınlanmamış Doktora Tezi). Atina: Panteıon Üniversitesi Siyaset Bilimi ve Tarih Anabilim Dalı

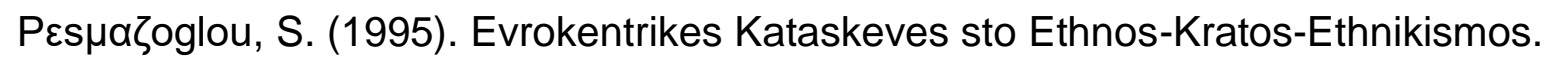
Epistimoniko Simposio (21-22 lanouariou 1994). Athina: Eteria Spoudon Neoellinikou Politismou kaı Genikis Paıdeias, ss. 187-195.

Rotzokos, N. (2007). Ethnafipnisi kaı Ethnogenisi. Orlofika kaı elliniki istoriografia. Athina: Vivliorama.

Paparrigopoulos, K. (1970). İstoria tou Ellinikou Ethnous. Atina: Hermes.

Pesmazoglou, S. (1993). İdeologia kaı ritoreia. Athina: Themelio.

Schnapper, D. (2005). Öteki ile Iliş̧ki. İstanbul: İstanbul Bilgi Üniversitesi.

Skopea, E. (1988). To prototipo vasileio kaı i Megali İdea. Opseıs tou ethnikou problimatos stin Ellada (1830-1880). Athina: Politipo.

Smith, A. (2000). Ethniki Tautotita. Athina: Odisseas.

Smith, A. (2001). Nationalism: theory, ideology, history. Cambridge: Polity.

Tekeli, İ. (1998). Tarihyazıcılığı ve öteki kavramı üzerine düşünceler. Tarih Eğitimi ve Tarihte "Öteki" Sorunu, II. Uluslararası Tarih Kongresi. İstanbul: Tarih Vakfı Yurt, ss. 1-6.

Veremis, Th. (2012). Ethiniki Tautotita kaı Ethnikismos sti Neoteri Ellada. Atina: MIET. 


\section{İncelenen Türkçe Kitaplar}

Akpınar, A. (2011). Çanakkale destanı -2, cephede bayram. İstanbul: Muştu.

Aydüz, Z. (2011). Osmanlı Tarihi, Yıldırım Beyazıd, Çelebi Mehmet ve II. Murat Dönemleri. İstanbul: Uğurböceği.

Bahadıroğlu, Y. (2009). Sel. İstanbul: Nesil.

Bahadıroğlu, Y. (2009/b). Küçük kahraman. İstanbul: Nesil.

Bahadıroğlu, Y. (2008). Vatan için. İstanbul: Nesil.

Boyunağa, A.Y. (2010). Korkusuz cengâver. İstanbul: Timaş.

Boyunağa, A.Y. (2011). Fetih sancakları. İstanbul: Timaş.

Boyunağa, A.Y. (2011/b). Malazgirt'in üç atıısı. İstanbul: Timaş.

Dikmen, S. (2012). Sultan Alparslan. İstanbul: Muştu.

Okay, F. (2010). İstanbul'un fethi. İstanbul: Gonca.

Oral, Ü. (2009). Küçük mehmetçikler. İstanbul: Bilgecan.

Dursun, Y. (2010). Sultandım Fatih oldum. İstanbul: Nar.

Dursun, Y. (2011). Anadolu Fatihi Sultan Alp Arslan. İstanbul: Nar.

Kaplan, S. (2000). Emre İstanbul'un fethinde. İstanbul: Alioğlu.

Subaşı, E. (2011). Sultan Alparslan. İstanbul: Mavi Lale Gençlik.

Teres, E. (2010). Gönderden inmeyen bayrak. İstanbul: Muştu.

Tücan, E. (2011). Çanakkale savaşı hikâyeleri 1. gönüllü askerler. İstanbul: Muştu.

Yeşılçayır, E. (2012). Fatih Sultan Mehmet. İstanbul: Muştu.

\section{İncelenen Yunanca Kitaplar}

Aleksiou, I. (1989). Iroes tou 21. Athina: Adelfotitos Theologon i Zoi.

Arvanitis, N. (1994). To Aıgaıo stis Floges. Athina: Apostolikis Diakonias tis Ekklisias tis Elladas.

Bikos, P. (1996). Androutsos, O Thrilos tis Gravias. Athina: Stratiki.

Bikos, P. (1999). Rigas Feraios, o Ethnomartiras tis Epanastasis. Athina: Stratiki. 
Dedousi, A. (2010). Matomena Stefania. Athina: Hristianikis Enoseos i Elpis.

Ferousis, D. (2007). Mihail Baknanas. Athina: Ateros.

Grigoriadou, G.S. (2005), To Dahtilidi tou Autokratora. Athina: Apostolikis Diakonias tis Ekklisias tis Elladas.

Madenlidis, İ. (2010). Anipohoritos Neomartis Larisis Ag. loannis o Monemvasiotis. Athina: Adelfotitos Theologon o Sotir.

Mousiopolou, K.P. (1992). Apo tin Mıkrasia me Agapi. Athina: Adelfotitos Theologon i Zoi.

Nikolopoulou, A. (2010). To Thelo Enos Thrilou. Athina: Apostolikis Diakonias tis Ekklisias tis Elladas.

Ntekastro, M. (2008). O Vizantinos stratos kaı to telos tou Vizantiou. Athina: Akritas

Servi, K. (2011). O Petros kaı i Epanastasi tou 1821. Athina: Skai. 


\section{Extended Summary}

\section{Purpose}

Who is the enemy? How do the peoples determine who their enemy is? How do the school, the family, the religious hierarchy, the media, the political actors, the international scene, and the intellectuals contribute to the formation both of the public opinion and the collective consciousness of each people? For example, a legacy that subconsciously shapes timeless stereotypes is often expressed in proverbs that are identical in a pair of languages. For instance, in the Turkish language and tradition there is the proverb "There is no friendship with a Greek or the fur of a bear", while almost the same proverb is to be found in the Greek language, namely "Turks are no good friends, as they are backstabbers". Another example is the phrases and the names, present in both languages, that refer to the Others. The Turkish language uses the expression "ellinosporos" to denote somebody who betrays their country, while the Greek language uses the expression "tourkosporos" to characterise somebody whose origin is not pure Greek. Another example is the idiom "I have become a Turk", which describes a person who is so outraged that they have lost control. Both of the above mentioned idioms -only two of dozens of similar ones- refer to stereotypes and prejudices. These are the tesserae that eventually form the mosaic, that is to say, the image and the stereotypes every people forms for the Other. Although they may superficially seem innocent and blithe, this is not always the case. They gradually poison the consciences and they subliminally create negative simplified images for the Other, turning them into a dangerous enemy. This process is not always spontaneous. More often than not, it is consciously directed by various interests (political, military, economic, religious), which are, to their benefit, transformed into historical destinies and emotional desires. They often cater to various special interests -for example, the aim at intimidation or at creating the sense that the Other is threatening, with the utter purpose to join the forces of the peoples. The image of the Other is an important issue, which can be researched in the dipole Turkey-Greece. The reason is that both communities, driven from their historical heritage, place the Other in the role of the opponent, who is both threatening and dangerous. In other words, Turkey and Greece use the Other in order to build their national identity and they do so by contrasting the 
image of the Other to themselves. The result of this contrast is the answer to the questions "Who is the Greek?" and "Who is the Turk?"

Object of this study is to analyze the image of "the other one" in historical involved child books in both Turkey and Greece by separating historical periods. Formation of perception of Turkish and Greek of their each other's is tried to explain on antithesis.

\section{Method}

Selection of the books that are placed in this research is based on the sociological method of grounded theory developed by Glaser and Strauss. Title of the books, identities of characters and age range that were intended to children is considered for selection of historical children books for comprising of history of both Turkish and Greek history. Inductive method is used for commenting of selected books according to data in the research and research has created its own theory by this obtained data notwithstanding any other theories. In other words we can explain the used grounded theory in this research with the words of Spanish poet Antonio Machado that is "There is no road, the road is made as you march." Issues in the analyzed books are involved the years 1453, 1821 and 1922 that are the important years for histories of both countries. Formation of these periods in history of both countries and positioning of "the other" and "me" relationship are analyzed comparatively. The purpose is to find out who "we are" more than to show "the other one" in perception of both Turkish and Greek. Using the histories of both countries as a propaganda mean is caused a contrary result to the scientific aspect of the research. Historical narration in these books which could be counted as "pop culture" work as a bond to bind perception and image of "the other one" in school books to minds of children. Also expression of "the other one" placed in these books are fulfilled and supplied the narrations in school books is observed personally.

\section{Findings and Discussion}

Three historical periods in Turkey and Greece History are comparatively analyzed in both Turkish and Greek child books and by this way how the creation of edition of "me/us" and "the other one" is examined in this part of the Study. 


\section{Result}

Both Turkish and Greek history education perceive the history as a lesson for future more than to illuminate the events of past, so they impersonate their each other as a character that is ever ready to harm the other one for this common historical heritage of their past. So accordingly, every historical narration has become a warning to "me" from "the other one". Sworn enemy perception is always reminded as a detailed that not to forget in history narration of both nations. "Me" is always unsurpassed and invincible. "The other one" is always trouble maker. Different historical narration for both Turkey and Greece which are established their national history on opposite direction is not having an unexpected surprising. The most important thing on studies for image about "the other one" is to find out the answers to the "reasons" of these images instead of "what" the images are. Also, the conditions of the terms and the results of these conditions on the conscience of the nation's should be examined and analyzed on the ground of differences between the historical narrations of both Turkey and Greece. Both nations have created their historical narration by following same codes for their historiography in Greece and Turkey. Primarily on these codes is to keep their own nationalism as stronger against to "the other one". All of the events are commented from viewpoint of "me" without giving a place to empathy. So, this kind of effort for superiority of their own nation against to the others causes moving away of both parts. So, common observation on Turkish - Greek History is that there is a sharp gap between "me" and "the other one" in history narration of both parts. 